\title{
RESOURCE CONSERVATION AND RECOVERY ACT INDUSTRIAL SITES \\ QUALITY ASSURANCE PROJECT PLAN \\ NEVADA TEST SITE, NEVADA
}

\author{
Prepared for: \\ DOE Nevada Operations Office \\ Las Vegas, Nevada \\ Prepared by: \\ IT CORPORATION \\ 4330 South Valley View Boulevard, Suite 114 \\ Las Vegas, Nevada
}

Work Performed under Contract No.:

DE-AC08-92NV10972

Revision: 0

June 1994

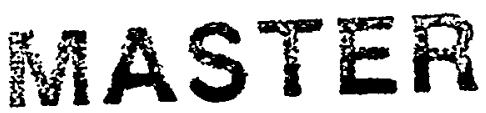

DISTRIBUTION OF THIS DOCUMENT IS UNLIMITED

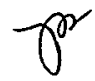




\section{DISCLAIMER}

This report was prepared as an account of work sponsored by an agency of the United States Government. Neither the United States Government nor any agency thereof, nor any of their employees, make any warranty, express or implied, or assumes any legal liability or responsibility for the accuracy, completeness, or usefulness of any information, apparatus, product, or process disclosed, or represents that its use would not infringe privately owned rights. Reference herein to any specific commercial product, process, or service by trade name, trademark, manufacturer, or otherwise does not necessarily constitute or imply its endorsement, recommendation, or favoring by the United States Government or any agency thereof. The views and opinions of authors expressed herein do not necessarily state or reflect those of the United States Government or any agency thereof. 


\section{DISCLAIMER}

Portions of this document may be illegible in electronic image products. Images are produced from the best available original document. 


\section{RESOURCE CONSERVATION AND RECOVERY ACT INDUSTRIAL SITES \\ QUALITY ASSURANCE PROJECT PLAN}

NEVADA TEST SITE, NEVADA

Revision: 0

Approved by: $\frac{S_{T e p h} A M_{e l l} \text { injtem }}{\text { Stephen A. Mellington }}$

Date: $6 / 21 / 94$

Project Manager

Nevada Environmental Restoration Project

Approved by: Saret Beperelle- Ding Date:6/21/94 Janet Appenzeller-Wing

Subproject Manager

RCRA Industrial Sites 


\section{Table of Contents}

List of Tables

List of Acronyms and Abbreviations $\ldots \ldots \ldots \ldots \ldots \ldots \ldots \ldots \ldots \ldots$

Definitions $\ldots \ldots \ldots \ldots \ldots \ldots \ldots \ldots \ldots \ldots \ldots \ldots \ldots \ldots \ldots \ldots \ldots$

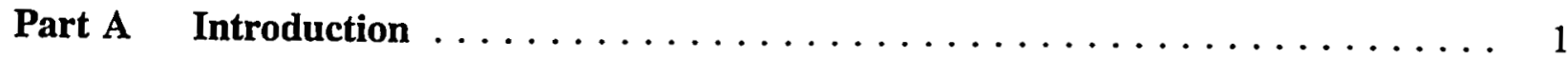

Introduction $\ldots \ldots \ldots \ldots \ldots \ldots \ldots \ldots \ldots \ldots \ldots \ldots \ldots \ldots \ldots \ldots \ldots \ldots$

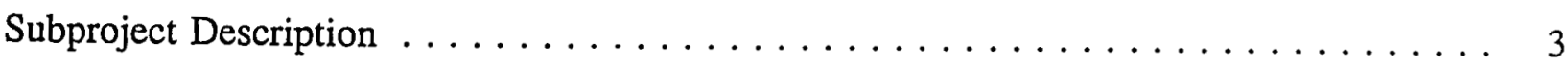

Part B Management $\ldots \ldots \ldots \ldots \ldots \ldots \ldots \ldots \ldots \ldots$

1.0 Criteria $1-$ Program $\ldots \ldots \ldots \ldots \ldots \ldots \ldots \ldots \ldots \ldots \ldots \ldots$

1.1 Organizations and Responsibilities $\ldots \ldots \ldots \ldots \ldots \ldots \ldots \ldots$

1.1.1 DOE/NV Project Manager . . . . . . . . . . . . . . . . . 8

1.1.1.1 DOE/NV Subproject Manager $\ldots \ldots \ldots \ldots \ldots \ldots$

1.1.1.2 DOE/NV Quality Assurance Coordinator ................ 9

1.1 .2 Nevada Test Site Office . . . . . . . . . . . . . . . . . . . 9

1.1.3 RCRA Industrial Sites Subproject Participants . . . . . . . . . . . . . 9

1.2 Quality Assurance Objectives for Measurements $\ldots \ldots \ldots \ldots \ldots \ldots$

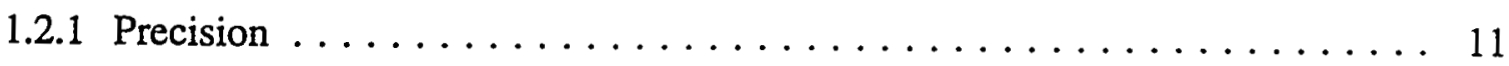

1.2 .2 Accuracy . . . . . . . . . . . . . . . . . . . . 14

1.2 .3 Representativeness ......................... 14

1.2 .4 Completeness . . . . . . . . . . . . . . . . . . . 15

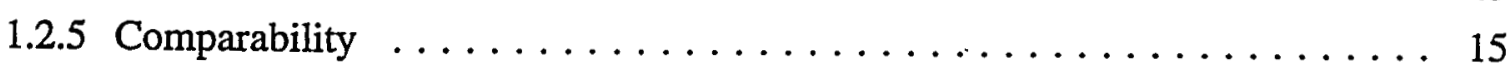

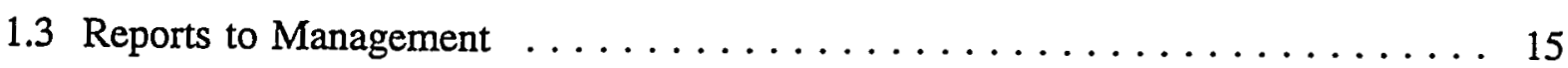

1.4 Readiness Reviews . . . . . . . . . . . . . . . . . . . . 16

1.5 Stop Work Order . . . . . . . . . . . . . . . . . . . . 17 
1.5.1 Stop Work Order Identification $\ldots \ldots \ldots \ldots \ldots \ldots \ldots \ldots \ldots \ldots$

1.5 .2 Stop Work Order Process $\ldots \ldots \ldots \ldots \ldots \ldots \ldots \ldots \ldots \ldots$

2.0 Criteria 2 - Personnel Training and Qualifications . . . . . . . . . . 19

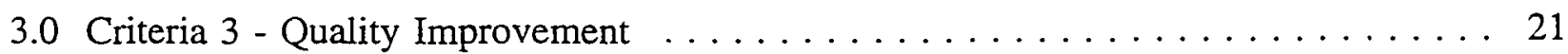

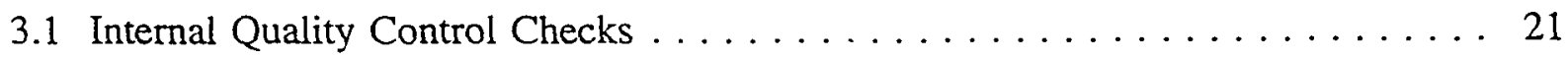

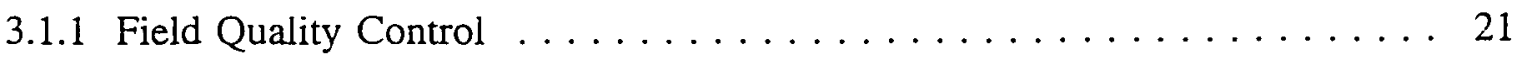

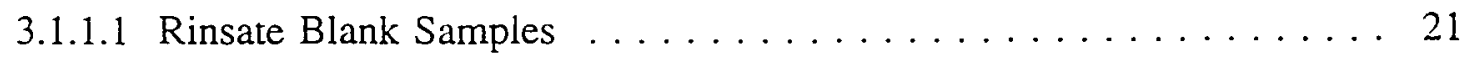

3.1.1.2 Field Blank Samples . . . . . . . . . . . 22

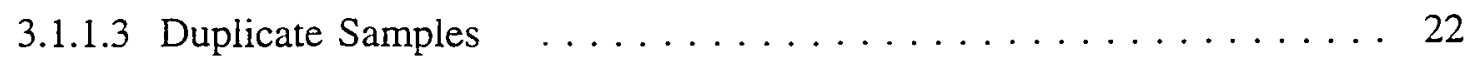

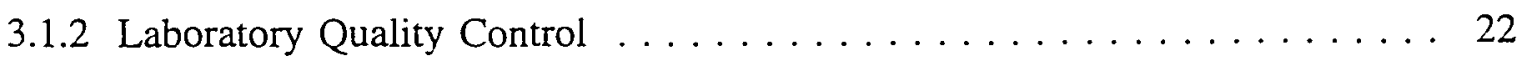

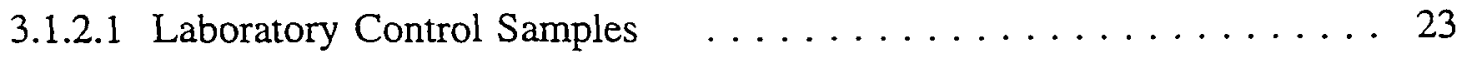

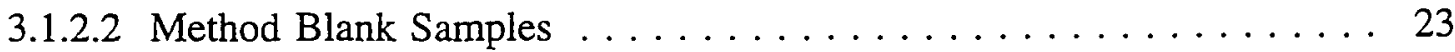

3.1.2.3 Surrogate-Spike Samples $\ldots \ldots \ldots \ldots \ldots \ldots \ldots \ldots \ldots \ldots 23$

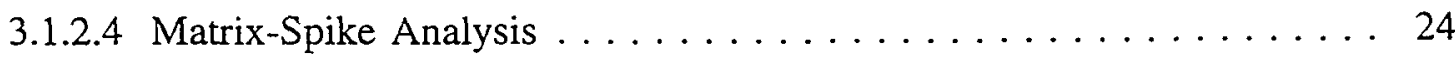

3.2 Specific Routine Procedures Used to Assess Data Precision. Accuracy. and

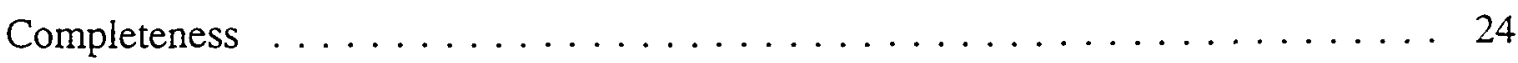

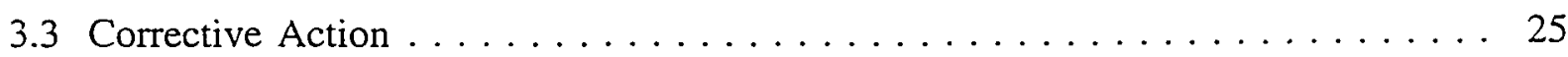

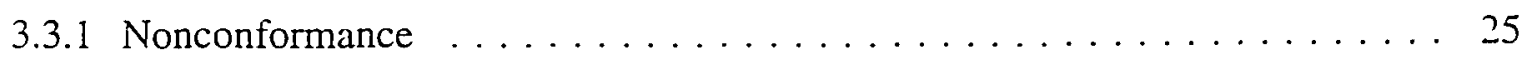

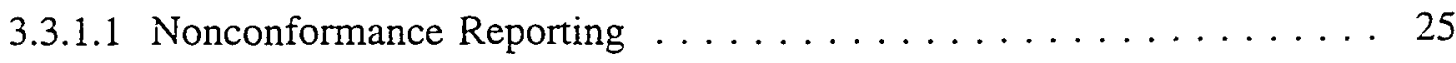

3.3.1.2 Nonconformance Trends . . . . . . . . . . . . . . . . . 27

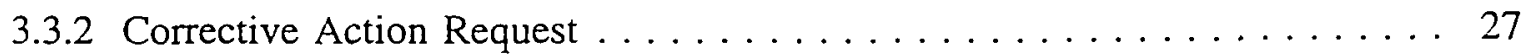

4.0 Criteria 4 - Documents and Records . . . . . . . . . . . . . . . . 29

4.1 Variances/Change Control . . . . . . . . . . . . . . . . . . . . 29

4.2 Document Review and Control . . . . . . . . . . . . . . . . . 29

4.3 Subproject Documentation and Maintenance $\ldots \ldots \ldots \ldots \ldots \ldots \ldots$ 


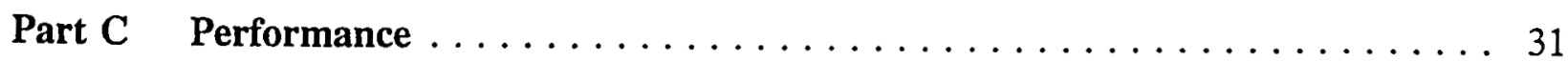

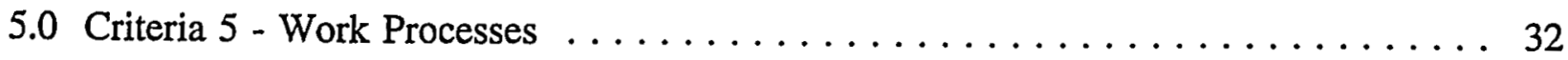

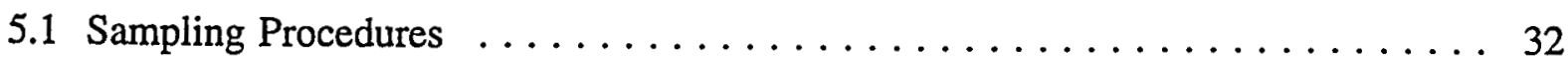

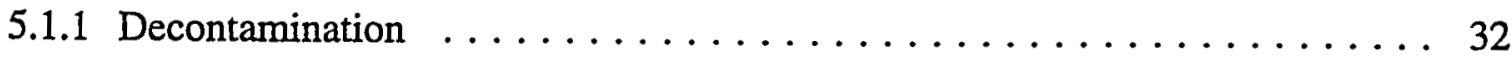

5.1 .2 Sample Handling and Preservation $\ldots \ldots \ldots \ldots \ldots \ldots \ldots \ldots \ldots \ldots \ldots$

5.1 .3 Field Documentation . . . . . . . . . . . . . . . . 35

5.1 .4 Photographic Documentation ................... 44

5.2 Sample Custody . . . . . . . . . . . . . . . . . . . . 44

5.2.1 Chain-of-Custody/Analysis Request Form ............... 44

5.2 .2 Sample Labels and Identification $\ldots \ldots \ldots \ldots \ldots \ldots \ldots$

5.2 .3 Custody Seals $\ldots \ldots \ldots \ldots \ldots \ldots \ldots \ldots \ldots \ldots \ldots$

5.2 .4 Sample Packaging and Shipping . . . . . . . . . . . . . 46

5.3 Analytical Procedures . . . . . . . . . . . . . . . . . 46

5.3.1 EPA Analytical Levels $\ldots \ldots \ldots \ldots \ldots \ldots \ldots \ldots \ldots \ldots$

5.3 .2 Analytical Methods . . . . . . . . . . . . . . . . . . . . . 49

5.4 Calibration and Preventive Maintenance . . . . . . . . . . . . . 49

5.4 .1 Calibration . . . . . . . . . . . . . . . . . . . . . 49

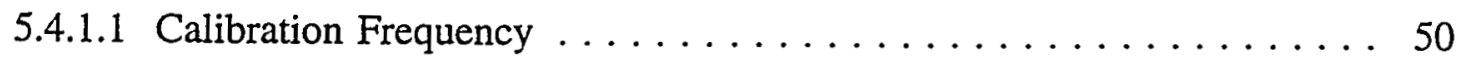

5.4 .1 .2 Reference Standards and Equipment $\ldots \ldots \ldots \ldots \ldots$

5.4 .1 .3 Calibration Failure $\ldots \ldots \ldots \ldots \ldots \ldots \ldots \ldots$

5.4 .2 Preventive Maintenance . . . . . . . . . . . . . . . . 51

5.5 Data Reduction, Validation, and Reporting ............... 51

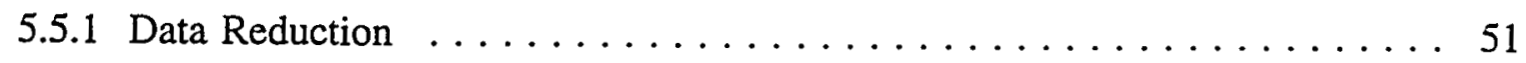

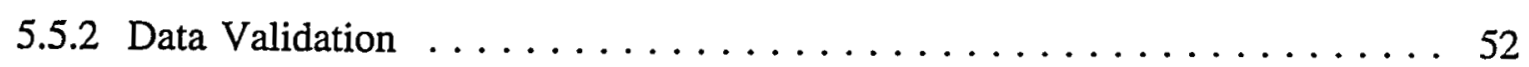

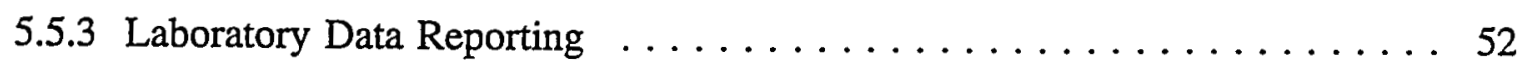

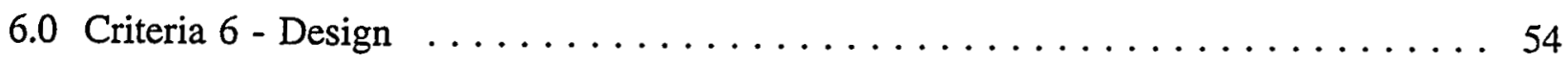

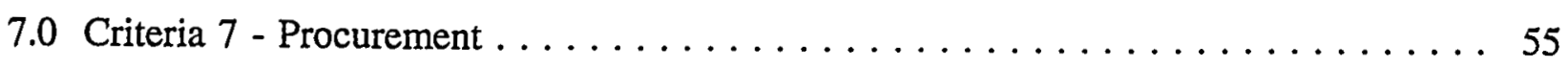




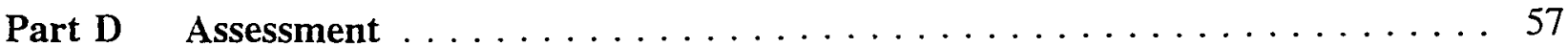

9.0 Criteria 9 - Management Assessment . . . . . . . . . . . . 58

10.0 Criteria 10 - Independent Assessments . . . . . . . . . . . . . . 59

10.1 Audits . . . . . . . . . . . . . . . . . . . . . . 59

10.1.1 Audit Schedule . . . . . . . . . . . . . . . . . . . 59

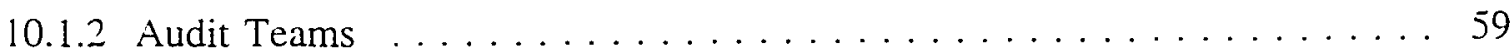

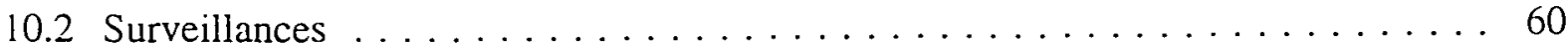

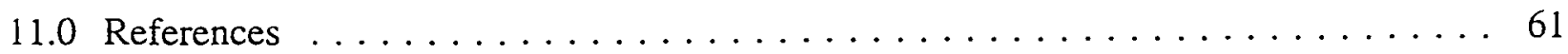




\section{List of Tables}

Number

I-1 Quality Assurance Project Plan Elements of QAMs-005 and Element Locations

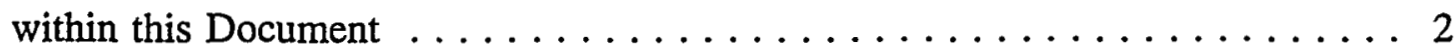

1-1 Assessment of Analytical Data Quality $\ldots \ldots \ldots \ldots \ldots \ldots \ldots \ldots 12$

1-2 Assessment of Sampling Data Quality $\ldots \ldots \ldots \ldots \ldots \ldots \ldots \ldots 13$

5-1 Field Procedures for Resource Conservation and Recovery Act Sites . . . . 33

5-2 Site Characterization and Closure Verification Analytical Requirements .... 36

5-3 Minimum Detectable Concentrations for Metals ............. 39

5-4 Waste Characterization Chemical Requirements ............. 40

5-5 Waste Characterization Radiological Requirements $\ldots \ldots \ldots \ldots \ldots$. . . 43

5-6 Summary of Analytical Levels Appropriate to Data Users . . . . . . . . . . 48 


\section{List of Acronyms and Abbreviations}

$\begin{array}{ll}\text { ASTM } & \text { American Society of Testing and Materials } \\ \text { CFR } & \text { Code of Federal Regulations } \\ \text { CLP } & \text { Contract Laboratory Program } \\ \text { COC/AR } & \text { Chain of Custody/Analysis Request } \\ \text { DOE } & \text { U.S. Department of Energy } \\ \text { DOE/NV } & \text { DOE Nevada Operations Office } \\ \text { DQO } & \text { data quality objective } \\ \text { EPA } & \text { U.S. Environmental Protection Agency } \\ \text { ER } & \text { Environmental Restoration } \\ \text { GC/MS } & \text { Gas Chromatography/Mass Spectrometry } \\ \text { H\&S } & \text { Health and Safety } \\ \text { LCS } & \text { laboratory control samples } \\ \text { LQC } & \text { Laboratory quality control } \\ \text { M\&TE } & \text { measurement and test equipment } \\ \text { NCR } & \text { Nonconformance Report } \\ \text { NIST } & \text { National Institute of Standards and Technology } \\ \text { NTS } & \text { Nevada Test Site } \\ \text { NTSO } & \text { Nevada Test Site Office } \\ \text { QA } & \text { quality assurance } \\ \text { QAC } & \text { Quality Assurance Coordinator } \\ \text { QAPjP } & \text { Quality Assurance Project Plan } \\ \text { QC } & \text { quality control } \\ \text { RAS } & \text { routine analytical services } \\ \text { RCRA } & \text { Resource Conservation and Recovery Act } \\ \text { REECo } & \text { Reynolds Electrical \& Engineering Co.. Inc. } \\ \text { RPD } & \text { relative percent difference } \\ \text { SAFER } & \text { Streamlined Approach for Environmental Restoration } \\ \text { SAP } & \text { Sampling and Analysis Plan } \\ \text { SOP } & \text { standard operating procedures } \\ \text { SWO } & \text { Stop Work Order } \\ & \end{array}$




\section{Definitions}

Acceptance Criteria - Specified characteristics of an item, process, or service defined in codes, standards, or other requirement documents.

Accuracy - A measure of the degree of agreement of a measurement (or an average of measurements of the same thing or mean of a set of results), X, with an accepted reference or true value, T. Accuracy is a measure of the bias in a system. Accuracy is assessed by means of reference samples and percent recoveries.

Activities that Affect Quality - Activities that, if not performed properly, could compromise the validity of information or data reported, could result in an unacceptable risk to the environmental health or safety of the public or the workers involved, or could have a detrimental effect on the achievement of the prime objectives of the project.

Audit - A planned and documented activity performed to determine by investigation, examination, or evaluation of objective evidence the adequacy of and compliance with established procedures, instructions, drawings, and other applicable documents, and the effectiveness of implementation. An audit should not be confused with surveillances or inspection activities performed for the sole purpose of process control or product acceptance.

Blank - A blank is an artificial sample designed to monitor the introduction of artifacts into the process. For aqueous samples, reagent water is used as a blank matrix; however, a universal blank matrix does not exist for solid samples, and, therefore, no matrix is used. The blank is taken through the appropriate steps of the process.

A reagent blank is an aliquot of analyte-free water or solvent analyzed with the analytical batch. Field blanks are aliquots of analyte-free water or solvents brought to the field in sealed containers and transported back to the laboratory with the sample containers. Trip blanks and equipment blanks are two specific types of field blanks. Trip blanks are not opened in the field. They are a check on sample contamination originating from sample transport and shipping and from site conditions. Equipment blanks are opened in the field, and the contents 


\section{Definitions (Continued)}

are poured appropriately over or through the sample collection device, collected in a sample container, and returned to the laboratory as a sample. Equipment blanks are a check on sampling device cleanliness.

Boring - Circular holes augured, washed, chopped, or drilled in or through soil or rock by the action of cutting tools for purposes of exploration.

Certification - The act of determining, verifying, and attesting in writing to the qualifications of personnel, processes, procedures, or items in accordance with acceptance criteria.

Characteristic - Any property or attribute of an item. process. or service that is distinct. describable, and measurable.

Checks - The tests, measurements, verifications, or controls placed on an activity by means of investigations, comparisons, or examinations to determine satisfactory condition, accuracy, safety, or performance.

Comparability - A measure of the confidence with which one data set can be compared to another.

Completeness - A measure of the amount of valid data obtained from a measurement system compared to the amount that was planned or that was expected to be obtained under correct normal conditions.

Condition Adverse to Qualitv - An all-inclusive term used in reference to any of the following: failures, malfunctions, deficiencies, defective items, and nonconformances.

Contamination (Contaminated) - Any unwanted undesirable foreign material on the surface of an item, in the atmosphere, or in process liquids or gases. A parameter in a specific environmental medium having a maximum source concentration above an action level or regulatory threshold. 


\section{Definitions (Continued)}

Corrective Action - Measures taken to rectify conditions adverse to quality and, where necessary, to preclude repetition.

Data (Technical) - Those data acquired from literature reviews, testing, analysis, measurement, inspection, or observation that relate to engineering or scientific matters.

Data - All administrative, managerial, financial, scientific, test, engineering, and analytical information and documentation required for delivery by contract, or developed within a program.

Data Quality - The totality of features and characteristics of data that bear on its ability to satisfy a given purpose. The characteristics of major importance are legibility, data accuracy, data precision, data completeness, data representativeness, and data comparability.

Data Quality Objectives - The predetermined objectives or goals for measurement data in terms of precision, accuracy, completeness, and representation.

Data Reduction - Any and all processes that change either the form of expression or quantity of data values or numbers of data items.

Data Validation - A systematic effort to review data to assure acceptable data quality. A systematic process for reviewing a body of data against a set of criteria to provide assurance that the data are adequate for their intended use. A systematic review process conducted to confirm the degree of truth in an analytical measurement.

Defensible - The ability to withstand any reasonable challenge related to veracity or truthfulness.

Deficiency - Lacking in some necessary quality or element.

Deviation - A departure from specified requirements. 


\section{Definitions (Continued)}

Dip - The direction of slope of layered formations.

Disposition - The action necessary to correct or resolve a nonconformance without regard to the root cause or action required to prevent recurrence.

Document - Any written or pictorial information describing, defining, specifying, reporting, or certifying activities, requirements, procedures, or results.

Examination - An element of inspection consisting of investigation of materials, components, supplies. and services to determine conformance to those specified requirements that can be determined by such investigation. Examination is usually nondestructive and includes simple physical manipulation, gauging, and measurement.

Finding - An apparent violation of an applicable federal law, DOE rule, order, a DOE-issued or approved procedure, or other significant deficient practice.

Hazardous Waste - Those wastes included in the definitions of Resource Conservation and Recovery Act (RCRA) 1004(5) and Revised Code of Washington (RCW) 70.105.010(15).

Independent (Personnel) - A condition characterizing an individual or group of individuals qualified to analyze, review, inspect. test. audit. or otherwise evaluate data and work results because they:

(a) had no direct responsibility for, or involvement in, performing the activity or work.

(b) are not accountable for the activity or work result.

(c) do not report directly to supervisors who are responsible for performing the activity or work to be evaluated.

Indoctrination - Instruction(s) that familiarizes a person with a particular subject but does not enable him to perform work. 


\section{Definitions (Continued)}

Inspection - Examination or measurement to verify whether an item or activity conforms to specified requirements.

Item - An all-inclusive term used in place of any of the following: appurtenance, assembly, component, equipment, material, module, part, structure, subassembly, subsystem, system, or unit.

Matrix/Spike Duplicate Analysis - In matrix/spike duplicate analysis, predetermined quantities of stock solutions of certain analytes are added to a sample matrix prior to sample extraction/digestion and analysis. Samples are split into duplicates, spiked, and analyzed. Percent recoveries are calculated for each of the analytes detected. The relative percent difference between the samples is calculated and used to assess analytical precision. The concentration of the spike should be at the regulatory standard level or the estimated or actual method quantitation limit. When the concentration of the analyte in the sample is greater than 0.1 percent, no spike of the analyte is necessary.

Measurement Parameter - Those chemical, physical, or biological attributes from which environmentally related measurement data are obtained.

Measurement System - The process for collection, analysis, and reduction of data designed to acquire environmentally related measurements.

Measuring and Test Equipment - Devices or systems used to calibrate, measure, gage, test, or inspect to (1) control or acquire data to verify compliance to specified requirements, (2) establish characteristics or values, or (3) make decisions or design facilities or processes.

Nonconformance - A deficiency in characteristic, documentation, or procedure that renders the quality of an item or activity unacceptable or indeterminate. 


\section{Definitions (Continued)}

Objective Evidence - Any documented statement of fact, other information, or record, either quantitative or qualitative, pertaining to the quality of an item or activity, based on observations, measurements, or tests that can be verified.

Precision - The measure of mutual agreement among individual measurements of the same property, usually under prescribed similar conditions. Precision is most desirably expressed in terms of the standard deviation. Various measures of precision exist depending upon the "prescribed similar conditions."

Procedure - A document that specifies or describes how an activity is to be performed.

Procurement Document - Purchase requisitions, purchase orders, drawings, contracts, specifications, or instructions used to define requirements for purchase.

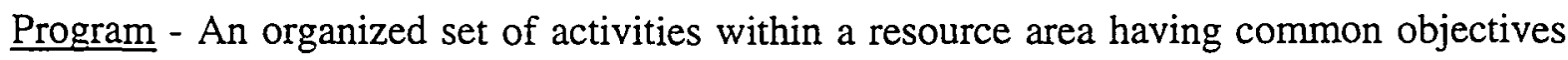
based on a strategy set forth to meet assigned goals. It may include one or more projects and research and development activities in support of new, improved, or more efficient supply, or conservation systems or procedures.

Qualification (personnel) - The characteristics or abilities gained through education, training, or experience, as measured against established requirements, such as standards or tests, that qualify an individual to perform a required function.

Qualification Tests - Tests performed to qualify the basic material source or manufacturer to assure conformance to specification requirements.

Qualified Procedures - A procedure that has been demonstrated to meet the specified requirements for its intended purpose.

Quality Assurance - Actions that provide confidence that quality is achieved. 


\section{Definitions (Continued)}

Quality Assurance Program - The overall program established by an organization to implement the requirements of DOE Order 5700.6C.

Quality Assurance Project Plan - Project quality assurance plans are written to support work plans or similar documents and describes how internal organizations are to implement their quality assurance responsibilities.

Quality Assurance Record - A completed document that furnishes evidence of the quality of items and/or activities affecting quality.

Quality Control - Activities that provide a means to control and measure the characteristics of an item, process, procedure, or service against established requirements.

Readiness Review - A systematic, documented review of the readiness for startup or continued extended use of a facility, process, or activity. Readiness reviews are typically conducted before proceeding beyond project milestones and prior to institution of a major phase of work activities.

Receiving - Taking delivery of an item at a designated location.

Repair - The process of restoring a nonconforming characteristic to a condition such that the capability of an item to function reliably and safely is unimpaired, even though that item still does not conform to the original requirement.

Replicate Sample - A replicate sample is a sample prepared by dividing a sample into two or more separate aliquots. Duplicate samples are considered to be two replicates.

Representativeness - The measure of the degree to which data accurately and precisely represent a characteristic of a population, parameter variations at a sampling point, or an environmental condition. 


\section{Definitions (Continued)}

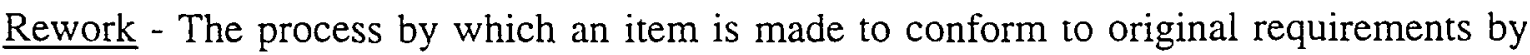
completion or correction.

Sample - An environmental sample or field sample is a representative sample of any material (aqueous, nonaqueous, or multimedia) collected from any source for which determination of composition or contamination is requested or required. For the purposes of this document, environmental samples shall be classified as follows:

- $\quad$ Surface water and groundwater

- Water/Wastewater - raw source waters for public drinking water supplies, groundwaters, municipal influents/effluents, and industrial influents/effluents

- Waste - aqueous and nonaqueous liquid wastes, chemical solids, contaminated soils, and industrial liquid and solid wastes.

Screening - Field or laboratory analyses using same or simpler analytical methods with less rigorous quality assurance/quality control requirements. Screening methods are characterized by quick turn-around time (results are available in real time or within a few hours or days as opposed to weeks or months typically required for validated laboratory data), and lower costs. However, screening results may not be compound specific. and the data may be qualitative or semiqualitative. Screening results may be directly representative of either a single laboratory contaminant parameter or a group of such parameters.

Service - The performance of activities, such as design, fabrication, inspection, nondestructive examination, repair, installation, or data acquisition.

Significant Condition Adverse to Quality - A significant condition adverse to quality is one which, if uncorrected, could have a serious effect on safety or operability.

Site - An aggregate area, operable unit, or waste management unit, as appropriate to the context of the project, as opposed to the term "Hanford Site," which refers to the entire DOE reservation. 


\section{Definitions (Continued)}

Site Characterization - The program of exploration and research, both in the laboratory and in the field, that is undertaken to establish the geologic conditions and the ranges of parameters of a particular site. Site characterization includes the analysis and interpretation of data from borings, surface excavations, excavation of exploratory shafts, limited subsurface lateral excavations and in situ testing at depth as needed to determine the suitability of the site, but does not include preliminary borings and geophysical testing needed to help provide a basis for determining whether site characterization should be undertaken.

Spike - The addition of a known quantity of an analyte to a blank, reference, or unknown sample. Used to assess accuracy and precision by evaluating percent recovery. Spikes are also use for analysis by the method of known addition.

Standard Operating Procedure - A written document that details an operation, analysis, or action for which mechanisms are thoroughly prescribed and that is commonly accepted as the method for performing certain routine or repetitive tasks.

Storage - The act of holding items in storage facilities.

Surveillance - The act of monitoring or observing a process or activity to verify conformance to specified requirements.

Surrogate - Organic compounds similar to analytes of interest in chemical composition, extraction, and chromatography, but that are not normally found in environmental samples. Percent recoveries are calculated for each surrogate.

Technical Review - A documented critical review of work that is within the state of the art. A technical review is an in-depth analysis and evaluation of documents, activities, material, or data for applicability, correctness, technical adequacy, completeness, appropriateness of interpretation, and assurance that established requirements are satisfied. 


\section{Definitions (Continued)}

Testing - An element of verification for determining the capability of an item to meet specified requirements by subjecting the item to a set of physical, chemical, environmental, or operating conditions.

Traceability - The ability to trace the history, application, or location of an item and like items or activities by means of recorded identification.

Training - Instruction that enables a person to perform a task or tasks.

Use-As-Is - A disposition permitted for a nonconforming item when it can be established that the item is satisfactory for its intended use.

Validated Data - Data are valid when the methods, practices. techniques, and equipment used to obtain and treat them are technically sound, based on objectivity, and selected properly. Data that the DOE has determined meet criteria contained in the "Data Validation Guidelines for Contract Laboratory Program Inorganic Analyses" that are contained in the Sample Management Administrative Manual.

Validation Data - The documented confirmation of the adequacy (i.e., the suitability for its intended purpose) of the work under review.

Verification Data - The act of reviewing, inspecting, testing, checking, auditing, or otherwise determining and documenting whether items, processes, services, or documents conform to specified requirements.

Verify - To determine or test the truth or accuracy by comparison or reference.

Waste Characterization - To describe the qualities, features, or traits of wastes, such as quantity of radioactive or chemical contaminants, flammability, corrosivity, or reactivity. Characterization is accomplished through sampling and analysis or process knowledge and controls. 
Resource Conservation and Recovery Act

\title{
Industrial Sites \\ Quality Assurance Project Plan
}

\author{
Part A \\ Introduction
}

Nevada Environmental Restoration Project 


\section{Introduction}

This quality assurance project plan (QAPjP) describes the measures that shall be taken to ensure that the environmental data collected during characterization and closure activities of Resource Conservation and Recovery Act (RCRA) Industrial Sites at the Nevada Test Site (NTS) are meaningful, valid, defensible, and can be used to achieve project objectives. These activities are conducted by the U.S. Department of Energy Nevada Operations Office (DOE/NV) under the Nevada Environmental Restoration (ER) Project. The Nevada ER Project consists of environmental restoration activities on the NTS, Tonopah Test Range, Nellis Air Force Range, and eight sites in five other states. The RCRA Industrial Sites subproject constitutes a component of the Nevada ER Project.

Currently, this QAPjP is limited to the seven RCRA Industrial Sites identified within this document that are to be closed under an interim status and pertains to all field-investigation, analytical-laboratory, and data-review activities in support of these closures. The information presented here supplements the RCRA Industrial Sites Project Management Plan and is to be used in conjunction with the site-specific subproject sampling and analysis plans.

The organization of this plan reflects the format of DOE Order 5700.6C, Quality Assurance. This format allows for the inclusion of $\mathrm{DOE}$ requirements that are in addition to U.S. Environmental Protection Agency (EPA) guidance. This QAPjP is divided into three major parts: Management, Performance, and Assessments. Management, Part B, entails the planning and preparation required for the successful completion of the subproject mission. Additionally, this section incorporates quality improvement processes to detect and prevent quality problems. Performance, Part $\mathrm{C}$, sets the requirements and procedures to be implemented to ensure that the environmental data collected are valid. Assessments, Part D, provides a feedback loop to subproject management whereby subproject management can use the information obtained to assess and, if necessary, modify a system or process to ensure the quality of the product. This QAPjP includes all of the essential elements of a QAPjP, as defined in Interim Guidelines and Specifications for Preparing Quality Assurance Project Plans, QAMS-005/80. Table I-1 lists the 16 essential elements of a QAPjP and the location of each element within this plan. 


\section{Table I-1 \\ Quality Assurance Project Plan Elements of QAMs-005 \\ and \\ Element Locations within this Document}

\begin{tabular}{||l|l||}
\hline \multicolumn{1}{|c||}{ Essential Element } & \multicolumn{1}{|c|}{ Location } \\
\hline \hline Title Page & Title Page \\
Table of Contents & Pages i-iii \\
Project Description & Part A \\
Project Organization and Responsibility & Section 1.1 \\
Quality Assurance Objectives for Data Measurement & Section 1.2 \\
Sampling Procedures & Section 5.1 \\
Sample Custody & Section 5.2 \\
Calibration Procedures and Frequency & Section 5.4 \\
Analytical Procedures & Section 5.3 \\
Data Reduction, Validation, and Reporting & Section 5.5 \\
Quality Control Checks & Section 3.1 \\
Audits & Sections 9.0 and 10.0 \\
Preventive Maintenance & Section 5.4 \\
Procedures to Assess Data Precision, Accuracy, and & Section 3.2 \\
Completeness & Section 3.3 \\
Corrective Action & Section 1.3 \\
Quality Assurance Reports to Management & \\
\hline
\end{tabular}




\section{Subproject Description}

Seven RCRA sites at the NTS are to be closed under interim status regulations. Some of the sites will be closed using the Streamlined Approach for Environmental Restoration (SAFER) and will be characterized and closed concurrently in accordance with site-specific closure plans. The remaining sites are currently planned to be closed under the traditional RCRA approach in accordance with separate subproject characterization and closure plans. However, it may be determined that the SAFER approach can be applied to other units.

The SAFER concept recognizes that technical decisions can be made by experienced subproject personnel faced with some procedural uncertainty. The SAFER concept involves documenting assumptions and a decision-making approach, then monitoring the program as the planned activities progress. If at any time new information indicates that a planned activity should be reevaluated, the activity is reconsidered and revised as necessary. Work then proceeds based on the new information and the revised strategy. This continuous refocusing of the activity results in streamlined, or focused, decision making.

Closure will occur by removal of the existing wastes until a predetermined standard is achieved (clean closure) or by immobilizing the wastes without removal (closure in place). The anticipated closure activities are described below.

\section{Area 27 Explosive Ordnance Disposal Unit}

The Area 27 Explosive Ordnance Disposal Treatment Unit is an open-burn, open-detonation RCRA unit as defined and regulated by Title 40 Code of Federal Regulations (CFR) Part 265, Subpart X. The unit was used to treat explosives and explosives-contaminated waste by detonation or burning. Site characterization and closure will proceed concurrently using the SAFER approach. The portion of the unit suspected to contain contaminants will be excavated and then sampled to determine whether the remaining soil meets predetermined closure standards. Various other portions of the unit will be sampled to determine whether excavation is necessary. The closure plan reflects this approach and will be revised, as necessary, to require additional excavation of any contamination discovered by the sampling. Closure will be documented by a report containing all of the data collected and describing the actual closure activities. 


\section{Area 23 Building 650 Leachfield}

The Area 23 Building 650 Leachfield is a mixed radioactive-waste-disposal unit as defined and regulated by Title 40 CFR Part 265, Subpart N. The unit received laboratory wastes from the analysis of environmental and industrial hygiene samples and, possibly, photographic development wastes. Closure will be conducted using the SAFER concept. Geophysical data will be gathered to determine unit boundaries and buried pipe locations, followed by limited sampling. If the initial data indicate excavation is not required, more extensive sampling will be conducted to confirm that closure is acceptable. If the initial data confirm the presence of contamination, if feasible, the unit will be excavated. Sampling will be conducted to confirm that remaining soils meet predetermined standards. The method of sampling will be accomplished by hand, a backhoe to dig a test pit, and/or a drill rig to bore test holes.

\section{Area 2 Bitcutter and Postshot Shops}

The Area 2 Bitcutter Shop and Postshot Decontamination Shop are three shallow wastedisposal wells as defined and regulated by Title 40 CFR Part 265, Subpart N. The wells received cleaning effluent contaminated with solvents, oils, and detergents. A records review and personnel interviews will be conducted, followed by surface-soil sampling to determine constituents of concern and their concentrations. Reaming or overboring the holes to remove contaminants is considered the preferred closure option. If waste removal is not feasible, closure in place will occur by filling the wells with cement. Boring of sampling wells and installation of monitoring wells may be required if wastes are left in place.

\section{Area 2 U-2bu Subsidence Crater}

The Area 2 U-2bu Subsidence Crater is a landfill as defined and regulated by Title 40 CFR Part 265, Subpart N. The crater received drilling muds from postshot borings and debris from miscellaneous cleanup actions. The crater is located in a valley containing numerous other subsidence craters. Closure in place is likely but possible clean closure will be investigated. Surface sampling, a detailed records review, and personnel interviews will be conducted in the first characterization phase to determine the possibility of excavating the crater to remove wastes and clean-close the unit. If clean closure is not practical, closure will occur in place. The closure plan will reflect the chosen option and may be modified as necessary. Vertical and/or slant boring and sampling will be conducted if closure in place is planned and useful 
data can be obtained. Vadose-zone moisture and vapor monitoring wells will be installed, if necessary.

\section{Area 6 Decontamination Pond Facility}

The Area 6 Decontamination Pond Facility is a surface impoundment as defined and regulated by Title 40 CFR Part 265, Subpart K. The impoundment received wastewater containing RCRA solvents, oils, and greases from the equipment being cleaned and, probably, entrained radioactive wastes. A modified SAFER concept will be used. The Site Characterization Plan will be revised and resubmitted, along with a closure plan reflecting clean closure. Sludge sampling, a records review, and a geophysical survey for pipeline location and moisture profiles will be conducted in the first characterization phase. After verification that all sources of water to the pond have been cut off and the pond has dried sufficiently, the closure plan will be implemented. Closure verification and the second phase of site characterization, waste sampling and analysis, will be conducted simultaneously. If waste constituents are to be left in place, soil boring sampling will be conducted, if necessary, to document the depth and spread of contamination. Vertical soil borings on the downdip side of the pond will be conducted to gather horizontal and vertical plume data. If necessary, lysimeters for vadosezone monitoring will be installed.

\section{Area 6 Steam-Cleaning Effluent Ponds}

The Area 6 Steam-Cleaning Effluent Ponds are two surface impoundments as defined and regulated by Title 40 CFR Part 265, Subpart K. The impoundments received wastewater contaminated with RCRA solvents, oils, and greases from the equipment being cleaned. Sludge sampling, a records review, and a geophysical survey for pipeline location and moisture profiles will be conducted in the first characterization phase. Water sources to the pond will be determined and cut off. The closure plan will be implemented when the pond has dried sufficiently. Closure verification and the second phase of site characterization, waste sampling and analysis, will be conducted simultaneously. If waste constituents are to be left in place, soil boring sampling will be conducted, if necessary, to document the depth and spread of contamination. Vertical soil borings will be conducted on the downdip side of the pond to gather horizontal and vertical plume data. If necessary, lysimeters for vadosezone monitoring will be installed. 


\section{Area 3 U-3fi Waste Well}

The Area 3 U-3fi Waste Well is a deep waste-disposal well as defined and regulated by Title 40 CFR Part 265, Subpart N. The well received radioactive wastes and drilling muds from postshot borings and may have received other undocumented wastes. The drilling muds contained RCRA metals. This unit is intended to be closed in place using the SAFER approach. Deep vadose-zone monitoring wells will be bored as part of closure activities to investigate waste movement. Vadose-zone vapor monitoring equipment will be installed in the boreholes for continued monitoring after closure is complete. 
Resource Conservation and Recovery Act Industrial Sites
Quality Assurance Project Plan

Part B

Management

Nevada Environmental Restoration Project 



\subsection{Criteria 1 - Program}

Management systems encompass the planning and preparation necessary to ensure that data obtained from environmental investigations are of adequate quality. Roles and responsibilities are defined and lines of communication established; the needs and objectives of the project are established; and reviews are conducted to ensure, to the extent possible, that all necessary planning and preparation have taken place.

\subsection{Organizations and Responsibilities}

A comprehensive list of roles and responsibilities is detailed in the RCRA Industrial Sites Subproject Management Plan. A synopsis of roles and responsibilities follows.

\subsubsection{DOE/NV Project Manager}

The DOE/NV Project Manager has technical oversight and management responsibilities for all activities within the Nevada ER Project. The Project Manager is the senior management official responsible for ensuring that this QAPjP is established and implemented, and that opportunities for improvement are identified and incorporated into the activities of the RCRA Industrial Sites Subproject.

\subsubsection{DOE/NV Subproject Manager}

The DOE/NV Subproject Manager reports directly to and is the prime point of contact with the DOE/NV Project Manager. The DOE/NV Subproject Manager has day-to day management responsibilities for the technical, financial, and scheduling aspects of the subproject and shall monitor contractor performance of subproject activities. At a minimum, the DOE/NV Subproject Manager shall:

- Review, approve, and direct the implementation of subproject plans

- Participate in the organization and planning of activities to consistently meet project quality objectives

- Disseminate pertinent information from $\mathrm{DOE} / \mathrm{NV}$ to subproject participants 
- Review and approve variances to subproject documents

- Notify the DOE/NV Project Manager, the DOE/NV Quality Assurance Coordinator (QAC), and other involved personnel of significant conditions adverse to quality or any identified trends

- Monitor the quality-achieving activities of participating organizations and provide direction and guidance for improvement.

\subsubsection{DOE/NV Quality Assurance Coordinator}

The DOENNV QAC reports to the DOE/NV Project Manager and has a direct line of communication with the DOE/NV Subproject Manager. The DOE/NV QAC is responsible for assisting subproject management in the development, verification, and implementation of this QAPjP and will provide the overall direction of the quality assurance (QA) function. At a minimum. the DOE/NV QAC shall:

- Identify and respond to QA and quality control (QA/QC) needs, resolve problems, and provide guidance or assistance

- Review and evaluate quality-related changes to the Sampling and Analysis Plan (SAP), the $\mathrm{QAPjP}$, and other documents that contain QA criteria

- Verify that appropriate corrective actions are taken for nonconformances

- Notify the DOE/NV Project Manager, the DOE/NV Subproject Manager, and other involved personnel of significant conditions adverse to quality or any adverse trends.

\subsubsection{Nevada Test Site Office}

The Nevada Test Site Office (NTSO) provides field direction and coordinates activities among contractors for NTS operations. The assigned NTSO Project Engineer ensures that the performance of any on-site activity is in compliance with approved plans, procedures, specifications, and QA requirements.

\subsubsection{RCRA Industrial Sites Subproject Participants}

All participants in the RCRA Industrial Sites Subproject are responsible for developing necessary procedures and ensuring that all work is performed in accordance with applicable federal, state, local, and DOE regulations; Nevada ER Project QA Program requirements; this 
QAPjP; and approved subproject plans and procedures. To fulfill responsibilities specific to $\mathrm{QA}$, the subproject participants shall, at a minimum:

- Report to the DOE/NV Subproject Manager on scope, schedules, costs, technical execution, and quality achievement of task order activities

- Ensure that proper resources and budget are provided for QA personnel and that QA activities are integrated into subproject activities

- Evaluate task order activities to ensure that planning document requirements are implemented

- Develop and implement procedures and instructions that govern RCRA Industrial Sites Subproject activities

- Ensure that work is technically sound, of acceptable quality, and consistent with subproject objectives

- Evaluate the qualifications of personnel and identify and provide additional training, as needed

- Ensure that personnel are trained and qualified to consistently achieve initial proficiency, maintain proficiency, and adapt to changes in technology, methods or job responsibilities

- Provide orientation and any necessary activity-specific training to field personnel on the requirements of this $\mathrm{QAPjP}$ and other subproject plans prior to the start of work

- Perform audits and surveillances to verify compliance with applicable requirements

- Identify deficient areas and implement effective corrective actions for quality problems

- Notify the DOE/NV Subproject Manager and other involved personnel of significant conditions adverse to quality or any adverse trends

- Verify that appropriate corrective actions are taken for nonconformances

- Track and trend nonconformances for conditions adverse to quality

- Ensure that all measurement and test equipment (M\&TE) is calibrated and that calibration is documented prior to use

- Establish and maintain a records management system. 


\subsection{Quality Assurance Objectives for Measurements}

QA objectives are qualitative and quantitative statements that specify the quality of data required to support subproject objectives. The overall objective of the RCRA Industrial Sites Subproject is to collect accurate and defensible data to assess the potential for migration of constituents of potential concern from RCRA units to adjacent areas. The indicators of data quality as related to sampling and laboratory analysis include precision, accuracy, representativeness, completeness, and comparability. The values selected for these data quality indicators are based on requirements for the field sampling and laboratory analytical programs and analytical data reporting. Specific QA objectives are discussed in detail in the following sections and in Tables 1-1 and 1-2.

\subsubsection{Precision}

Precision is a quantitative measure of the variability of a group of measurements from their average value. Precision shall be assessed by collecting and analyzing duplicate field samples and then by creating and analyzing laboratory duplicates from one or more field samples. Precision shall be reported as relative percent difference (RPD). The RPD is calculated as the difference between the measured concentrations of Sample 1 and Sample 2. divided by the average of the two concentrations. and multiplied by 100 .

Overall measurement precision is determined from the analytical results of duplicate field samples. Analytical results for laboratory duplicates provide a measure of analytical precision. The difference between measurement and analytical precision defines sampling precision.

Precision goals have been standardized for analytical laboratories under the EPA Contract Laboratory Program (CLP) (EPA, 1987). The historical precision of CLP Routine Analytical Services (RAS) methods has been determined from laboratory spike and quarterly blind performance evaluation samples. The precision goals for each parameter are either \pm 20 or 25 percent relative deviation from the average value, depending upon the parameter. 


\section{Table 1-1}

\section{Assessment of Analytical Data Quality}

\begin{tabular}{|c|c|c|c|}
\hline Parameter & Minimum Requirements & $\begin{array}{c}\text { Impacts of Failure to Meet } \\
\text { Objectives }\end{array}$ & Corrective Action(s) \\
\hline Completeness & 80 percent. & $\begin{array}{l}\text { Incomplete content and site } \\
\text { characterization. }\end{array}$ & $\begin{array}{l}\text { Determine whether the missing } \\
\text { data are needed. Can remaining } \\
\text { sample volumes be used or do } \\
\text { they need to be resampled? }\end{array}$ \\
\hline Comparability & $\begin{array}{l}\text { Equivalent samples analyzed as } \\
\text { per the sampling and analysis } \\
\text { plan (SAP) (Section } 4.0 \text { ); same } \\
\text { analytical methods, same units of } \\
\text { measurement and detection } \\
\text { limits must be used for like } \\
\text { analyses. }\end{array}$ & Increase in overall error. & $\begin{array}{l}\text { Implement comparable analytical } \\
\text { techniques or change } \\
\text { laboratories. }\end{array}$ \\
\hline Representativeness & $\begin{array}{l}\text { Sample-preparation requirements } \\
\text { as per the SAP that will not } \\
\text { introduce a bias. }\end{array}$ & $\begin{array}{l}\text { Inaccurate identification or } \\
\text { estimate of concentration of } \\
\text { contaminant. Insufficient data to } \\
\text { make decision(s). }\end{array}$ & $\begin{array}{l}\text { Reanalyze, resample, or } \\
\text { document which site areas are } \\
\text { poorly characterized. }\end{array}$ \\
\hline Precision & $\begin{array}{l}\text { Laboratory duplicates and/or } \\
\text { matrix spike/matrix spike } \\
\text { duplicate (MS/MSD) per } \\
\text { analytical batch on required } \\
\text { samples. Variation between } \\
\text { duplicates shall not exceed } 20 \% \\
\text { relative deviation from the } \\
\text { average value. }\end{array}$ & $\begin{array}{l}\text { Increased variability in data can } \\
\text { cause loss of completeness } \\
\text { which diminishes } \\
\text { representativeness such that } \\
\text { laboratory quality assurance (QA) } \\
\text { objectives cannot be satisfied. }\end{array}$ & $\begin{array}{l}\text { Reanalyze, resample, review } \\
\text { laboratory protocols, or use a } \\
\text { different analytical technique. }\end{array}$ \\
\hline Accuracy & $\begin{array}{l}\text { Laboratory spikes within quality } \\
\text { control criteria as specified in the } \\
\text { analytical method. } \\
\text { Laboratory method blanks below } \\
\text { required detection limit. }\end{array}$ & $\begin{array}{l}\text { Decrease in refiability can cause } \\
\text { loss of completeness which } \\
\text { diminishes representativeness } \\
\text { such that laboratory QA } \\
\text { objectives cannot be satisfied. }\end{array}$ & $\begin{array}{l}\text { Reanalyze or use different } \\
\text { analytical approach. }\end{array}$ \\
\hline
\end{tabular}




\section{Table 1-2}

\section{Assessment of Sampling Data Quality}

\begin{tabular}{|c|c|c|c|}
\hline Parameter & Minimum Requirements & $\begin{array}{l}\text { Impacts of Failure to Meet } \\
\text { Objectives }\end{array}$ & Corrective Action \\
\hline Completeness & 80 percent. & $\begin{array}{l}\text { Lack of complete content and site } \\
\text { characterization. }\end{array}$ & $\begin{array}{l}\text { Resample or provide additional } \\
\text { analysis of samples at } \\
\text { laboratory to complete data set } \\
\text { for lost samples. }\end{array}$ \\
\hline Comparability & $\begin{array}{l}\text { All samples are biased as per } \\
\text { the sampling and analysis plan } \\
\text { (SAP) (Section } 4.0 \text { ). Approved } \\
\text { procedures shall be used to } \\
\text { ensure comparability of sample } \\
\text { collection. }\end{array}$ & $\begin{array}{l}\text { Reduction in data confidence and } \\
\text { ability to detect data anomalies. }\end{array}$ & $\begin{array}{l}\text { Redesign sample collection } \\
\text { methods and/or add more } \\
\text { samples to increase confidence. }\end{array}$ \\
\hline Representativeness & $\begin{array}{l}\text { Sufficient numbers of samples } \\
\text { must be collected. Samples } \\
\text { must be representative of the } \\
\text { potentially contaminated } \\
\text { medium. Sample collection must } \\
\text { not alter sample. }\end{array}$ & $\begin{array}{l}\text { Generation of false negative data. } \\
\text { Data biased either high or low for } \\
\text { contaminant concentration. }\end{array}$ & $\begin{array}{l}\text { Additional sampling required. } \\
\text { Redesign sample collection } \\
\text { methods. }\end{array}$ \\
\hline Precision & $\begin{array}{l}\text { At least } 5 \text { percent of samples, } \\
\text { with not less than one duplicate } \\
\text { per day. Variations between } \\
\text { field duplicates should not } \\
\text { exceed } 20 \text { percent relative } \\
\text { deviation from the average } \\
\text { value. }\end{array}$ & $\begin{array}{l}\text { Unacceptable levels of } \\
\text { uncertainty. } \\
\text { Erroneous final decision(s). }\end{array}$ & $\begin{array}{l}\text { Resample or add more } \\
\text { samples. } \\
\text { Adjust performance objectives. }\end{array}$ \\
\hline Accuracy & $\begin{array}{l}\text { Adequate documentation that } \\
\text { every validated datum is } \\
\text { traceable to a specific location in } \\
\text { the prescribed sequence. } \\
\text { Sample spikes within quality } \\
\text { control criteria as specified in the } \\
\text { analytical method (may reflect } \\
\text { matrix-induced bias). Trip, } \\
\text { rinsate, and equipment blanks } \\
\text { below required detection limit. }\end{array}$ & $\begin{array}{l}\text { Loss of representativeness and } \\
\text { possible invalidation of all project } \\
\text { data. }\end{array}$ & Resample. \\
\hline
\end{tabular}


Variations between field duplicates should not exceed these limits. Values outside these limits may trigger corrective actions. Subsample precision of less than or equal to \pm 20 percent is difficult to obtain for soils and may not require corrective action measures in accordance with this QAPjP as determined by the DOE/NV Subproject Manager.

\subsubsection{Accuracy}

Analytical accuracy is defined as the nearness of a measurement to the true or accepted reference value. It is the composite of the random and systematic components of the measurement system and measures bias in a measurement system. The random component of accuracy shall be measured and documented through the analyses of spiked samples. Sampling accuracy shall be assessed by evaluating the results of field or trip blanks and laboratory control samples. Matrix-spike samples shall be analyzed for metal analytes and surrogate-spike samples shall be analyzed for organic analytes. Accuracy measurements for spike samples and laboratory control samples shall be calculated as percent recovery, which is calculated by dividing the measured sample concentration by the true concentration and multiplying the quotient by 100 . The percent recovery shall be within the limits specified in the analytical method.

Target analyte concentrations in blanks shall be below laboratory reporting limits or not detected. with the exception of acetone, methylene chloride. toluene, methyl ethyl ketone, and phthalate esters, which are common laboratory contaminants. Action levels for these compounds shall be at or below 10 times the corresponding laboratory reporting limits (EPA, 1990). Values exceeding acceptance criteria shall be evaluated for corrective actions.

Field accuracy shall be assessed by confirming that the documents of record track the sample from its origin through transfer of custody to its disposal. The goal of field accuracy is that all samples be collected from the right locations at the right time and then placed in a correctly labeled container with the correct preservative and sealed with custody tape to prevent tampering.

\subsubsection{Representativeness}

Representativeness expresses the degree to which sample data accurately and precisely represent a characteristic of a population, parameter variations at a sampling point, or an 
environmental condition (EPA, 1987). Sample representativeness shall be achieved through the implementation of a sampling program designed to ensure proper sampling locations and number and the use of validated analytical methods. Representativeness shall be assessed by the collection and analysis of replicate samples.

\subsubsection{Completeness}

Completeness is defined as a measure of the amount of usable, valid data obtained from a measurement system compared to the amount that was expected under correct normal conditions. Completeness is affected by unexpected conditions that may occur during the data collection process. Completeness shall be determined by comparison of the number of samples planned to be collected to the number of samples for which acceptable analytical results are received. Sample data completeness shall be achieved through quality sampling practices and standard analytical techniques that have been demonstrated to be 80 to 85 percent complete on a nationwide basis (EPA, 1987). A completeness objective is set at 80 percent. The analytical program is designed to minimize the data collection effort; therefore, it is anticipated that rejection of data and subsequent resampling will be minimal.

\subsubsection{Comparability}

Comparability is a qualitative parameter expressing the confidence with which one data set can be compared to another (EPA, 1987). Standardization of the sampling approach and analytical methods should result in comparability of data. To ensure comparability, all field and laboratory activities shall be performed and documented in accordance with approved procedures.

\subsection{Reports to Management}

Fundamental to the success of this subproject is the active participation of management in the RCRA Industrial Sites Subproject. Laboratory and field management shall be aware of subproject activities, as applicable, and shall participate in the development, review, and operation of the subproject. Management of all participants shall be informed of qualityrelated activities through the receipt, review, and/or approval of: 
- Subproject-specific QA plans and procedures

- Audit schedules

- Postaudit reports and audit closures

- Corrective action and schedules

- Corrective action requests

- Nonconformance reports

- Surveillance reports

- Management assessments.

Section 10.1 describes the audit process to be used during this subproject. In addition, periodic assessment of QA/QC activities and data accuracy, precision, and completeness shall be conducted and reported to the participating subproject field and laboratory management.

\subsection{Readiness Reviews}

Readiness reviews shall verify that all planning documents and systems are in place for the successful and efficient accomplishment of the mission.

Subproject participants shall perform readiness reviews prior to the start of any major scheduled activity and prior to restarting work following Stop Work Orders (SWOs) to verify and document that subproject planning and prerequisites have been satisfactorily completed. These reviews shall include subproject management, health and safety, and QA personnel. At a minimum, readiness reviews shall verify that:

- The scope of work is compatible with subproject objectives.

- The planned work is appropriate to meet objectives.

- Work instructions have been reviewed for adequacy and appropriateness, formally approved, and issued to personnel who will be performing the work.

- Proper resources (e.g., personnel, equipment, and materials) have been identified and are available.

- Assigned personnel have read the applicable work instructions and have been trained and qualified.

- Internal and external interfaces have been defined. 
- Proper work authorizations and permits have been obtained.

- The calibration of all material and test equipment is current.

\subsection{Stop Work Order}

An SWO shall be initiated when a condition adverse to quality is identified that, if allowed to continue, would result in personal injury, damage to DOE equipment or property, or have an adverse impact on mission accomplishment, budget, or schedule. If imminent danger exists, an SWO may be verbally imposed. An SWO may be limited to a specific activity, item, or design or it may be broad in scope and encompass all activities relating to the deficiency or violation.

\subsubsection{Stop Work Order Identification}

All individuals are empowered with the authority to stop work when continuing work may result in:

- Failure to adequately control the processing, delivery, installation, modification or operation of a nonconforming item

- Serious failure or breakdown of the QA program

- Significant hazard to those items or activities that are important to health and safety, the environment. or the mission of the project.

Resumption of work shall begin only upon completion of the necessary actions specified on the SWO and approval of the DOENV Subproject Manager. Health and Safety (H\&S) related SWOs shall require the additional signature of the DOE/NV H\&S Manager or a designee, in accordance with the Nevada ER Project Health and Safety Plan.

\subsubsection{Stop Work Order Process}

In accordance with DOE Order 5700.6C, all subproject participants shall develop and implement procedures governing SWOs. These procedures shall clearly delineate the reporting responsibilities and lines of communication. At a minimum, the procedures shall include: 
- Immediate verbal notification to the supervisor or manager of the responsible organization of the intent to issue an SWO

- Verbal notification of DOE and contractor subproject management when an SWO has been verbally imposed

- A written SWO issued to the responsible organization. 


\subsection{Criteria 2 - Personnel Training and Qualifications}

Contractor subproject management shall ensure that personnel are qualified and knowledgeable in the activities they perform. All RCRA Industrial Sites Subproject participants shall be responsible for maintaining personnel qualification and training records as quality documents.

\section{Project Personnel}

Personnel assigned to the RCRA Industrial Sites Subproject shall be trained and qualified to perform the tasks to which they are assigned. All contractors and support agencies shall establish minimum education, experience, and training requirements for activities to be performed.

Objective evidence of qualifications may include academic credentials, personal resumes, registrations and/or certifications, licenses, and training records. The qualifications of personnel involved in quality-related activities shall be evaluated against assigned responsibilities and documented. Based on the results of the evaluation, any additional training needs shall be identified, provided, and documented.

Training shall be provided to achieve initial proficiency; maintain proficiency; and adapt to changes in technology, methods, or job description. Contractor subproject management shall be responsible for providing personnel with the instructions necessary to perform qualityrelated activities. Training may take the form of orientation and/or indoctrination, formal classroom training, or on-the-job training. This training shall include contractual and regulatory requirements, scopes of work, QA/QC compliance requirements, and applicable work instructions. On-the-job training shall be conducted and documented by personnel qualified to perform the task. Any work performed by a trainee shall be under the supervision of a qualified individual.

\section{Analytical Laboratory Personnel}

Each analytical laboratory shall establish job descriptions for positions affecting data quality. These descriptions shall provide the minimum qualifications in terms of education, experience, and skills necessary for an analyst to carry out duties in the laboratory. Objective 
evidence of an individual's qualifications may include academic credentials, personal resumes, certifications, qualifying analytical test results, and training records. Laboratories shall provide appropriate orientation and/or training of the laboratory QA program and subproject requirements and must implement a performance-based qualification program which includes periodic requantification for analysts performing work for the RCRA Industrial Sites Subproject. 


\subsection{Criteria 3 - Quality Improvement}

Processes shall be established that prevent as well as detect and correct problems that adversely affect quality during all phases of technical and management activities. Personnel at all levels are encouraged to identify process improvement opportunities and problems and offer solutions to those problems. The following sections identify processes that, at a minimum, shall be implemented.

\subsection{Internal Quality Control Checks}

Field and laboratory investigation activities shall include the collection and analysis of QC samples to determine whether data generated meet the data quality objectives (DQOs) of the subproject. These samples shall be introduced into the analytical process in order to assess the overall quality of the sampling and analysis program. This section describes the QC samples that will be generated.

\subsubsection{Field Quality Control}

Sample collection shall be conducted in accordance with the procedures discussed in Section 5.0 of this QAPjP. In addition, the sampling team shall collect QC samples to assess and document the accuracy and precision of the collection process. The results of the analyses of these QC samples shall be included in the analytical report. The requirements for the number of QC samples will depend on the types and number of environmental samples collected.

Field QC samples include rinsate blanks, field blanks, and field duplicates.

\subsubsection{Rinsate Blank Samples}

One rinsate blank shall be submitted to the laboratory for each sampling activity requiring equipment decontamination to assess the overall cleanliness of the sampling system and the effectiveness of sampling-equipment decontamination procedures. The blanks shall be prepared by pouring deionized water (American Society of Testing and Materials [ASTM] Type II-quality) through or over a decontaminated sampling device prior to the use of the device for environmental sample collection. Sample management and documentation procedures for rinsate blanks shall be the same as those used for environmental samples. 
Rinsate blanks shall be analyzed in the same manner as the environmental samples. If rinsate blank analytical results indicate possible contamination of samples. environmental sample results shall be reviewed to determine whether qualifiers should be assigned to the data or if the source should be resampled.

\subsubsection{Field Blank Samples}

One field blank shall be submitted with each shipment of samples sent to the laboratory to determine if contamination in the air during sample collection and packaging may have contaminated the samples. The field blanks shall be prepared by pouring deionized water into clean sample containers in the field near the sampling locations. Sample management and documentation procedures for field blanks shall be the same as. those used for environmental samples. Parameters to be analyzed are listed in Section 5.0 of this QAPjP. If field blank analytical results indicate possible contamination of associated samples. environmental sample results shall be reviewed to determine whether qualifiers should be assigned to the data or the source resampled.

\subsubsection{Duplicate Samples}

One duplicate sample shall be collected for every 20 samples collected and analyzed to assess sample variability. If fewer than 20 samples are collected, one duplicate sample shall be collected for the sample group. The duplicates shall be obtained from the same depth horizon and approximately the same horizontal position as the original sample. A unique sample number shall be assigned to the duplicate sample. The duplicate sampie number shall not indicate that it is a QC sample to minimize handling, analysis, and data-evaiuation bias. Sample management and documentation procedures for duplicates shall be the same as those used for environmental samples. Collection of the required number of duplicates sinall be evenly distributed throughout the sampling project. Parameters to be analyzed shall be the same as those analyzed for the corresponding environmental samples.

\subsubsection{Laboratory Quality Control}

All laboratories performing analyses shall conduct their activities in accordance with a written and approved QA Plan. Laboratory quality control (LQC) samples shall be analyzed using the same analytical procedures used to analyze environmental samples. Each analytical laboratory shall generate QC samples during each analytical run to assess and document 
accuracy and precision associated with each analytical measurement. All data from concurrently analyzed LQC samples used to demonstrate analytical control shall be included in the analytical report. The requirements for the types and number of LQC samples will depend on the method and analytical level of each test. LQC samples include laboratory control samples (LCS), method blanks, surrogate-spike, matrix-spike, and matrix-spike duplicate samples.

\subsubsection{Laboratory Control Samples}

For nonorganic analyses, one LCS shall be analyzed with each batch of samples. The LCS (i.e., spiked, blank, or matrix samples) shall be carried throughout the sample preparation and analysis procedures to assess laboratory accuracy and precision. The LCS shall be analyzed concurrently with each analytical batch for each analyte of interest. The LCS shall be prepared from standards independent of the calibration standard. Control limits for recovery shall be established and recovery data plotted on internal control charts. LCS data outside these recovery limits shall be considered "out of control," and the laboratory shall initiate corrective action(s) that shall be performed in accordance with the laboratory's QA plan. Results of duplicate LCS analysis shall be reported as RPD and percent recovery and included with the associated analytical report.

\subsubsection{Method Blank Samples}

Method blanks shall be analyzed by the laboratory to check for contamination and interference from reagents used in the analytical method. A method blank shall be concurrently prepared and analyzed for each analyte of interest for each analytical batch. Method blank data outside statistical control limits shall be considered "out of control," and corrective action(s) shall be performed in accordance with the laboratory's QA plan. Method blank data shall be reported in the same units as the corresponding environmental samples and the results shall be included with each analytical report.

\subsubsection{Surrogate-Spike Samples}

Surrogate-spike sample analysis shall be performed for all samples analyzed by gas chromatography/mass spectrometry (GC/MS) to monitor the percent recovery of the sample preparation and analytical procedures on a sample-by-sample basis. Surrogate standards are nontarget compounds added to GC/MS standards, blanks, and samples prior to extraction or 
purging. Surrogate compounds and concentrations added shall be those specified in the applicable analytical method. Recovery values for surrogate compounds shall be within the control limits specified by the laboratory and in accordance with assessment procedures in the laboratory's QA plan or the analysis shall be repeated. Results of surrogate-spike sample analyses shall be reported as percent recovery.

\subsubsection{Matrix-Spike Analysis}

For other organic analysis, a separate sample aliquot shall be spiked with the analyte of interest and analyzed with every 20 samples or, if fewer than 20 samples were collected, with all of the samples. Subproject site-specific matrix-spike or matrix-spike-duplicate samples shall be analyzed by the laboratory to determine interferences of the sample matrix on the analytical methods and subsample variance of the composite samples. Results shall be included in the analytical report.

\subsection{Specific Routine Procedures Used to Assess Data Precision, Accuracy, and Completeness}

QC sample results shall be used to evaluate laboratory and field precision and accuracy. Precision shall be determined by comparing the concentrations of the various constituents between duplicate analyses. Accuracy shall be checked by introducing spiked samples into the laboratory sample stream for analysis. Accuracy may then be determined by comparing analytical results with the accepted. true value. The accuracy of the spiked samples must be within the accepted accuracy of the method of analysis for the analyte of interest. Sample results falling outside of acceptable ranges for precision and accuracy shall be brought to the attention of laboratory management for evaluation and corrective action(s), as needed. Completeness shall be determined by comparison of the number of samples expected to be collected to those samples for which acceptable analytical results are received. An objective of 80 percent completeness or greater has been set for the RCRA Industrial Sites Subproject.

Laboratory results shall be checked upon receipt. If there appears to be an error in the analysis, the laboratory shall be contacted immediately and corrective action(s) must be taken. If investigation reveals that processes were not in control, corrective action(s) shall be taken as outlined in Section 3.3 of this QAPjP. 


\subsection{Corrective Action}

This section establishes the methods and responsibilities for identifying, reporting, controlling, and resolving conditions of nonconformance and significant conditions adverse to quality for activities performed in support of the RCRA Industrial Sites Subproject.

\subsubsection{Nonconformance}

A nonconformance is a deficiency in characteristic, documentation, or procedure that renders the quality of an item or activity unacceptable or indeterminate (NQA-1-1989).

\subsubsection{Nonconformance Reporting}

RCRA Industrial Sites Subproject participants shall implement approved procedures for the identification, documentation, and resolution of nonconforming conditions. With the exception of the laboratories, nonconformances for this subproject shall be reported in accordance with NTS SOP-6401 Appendix, Section 4.0, Paragraph D, using the approved DOE/NV Nonconformance Report (NCR) Form (Figure 3-1). Laboratories may use internal forms, providing the forms include the required components listed below. All NCRs shall be processed in accordance with internal procedures. An NCR shall specify:

- Originator

- Date of the nonconformance

- NCR number (serialized)

- Responsible organization

- Requirement(s)

- Nature of the nonconformance

- Disposition

- Technical justification

- Approximate cost to implement the disposition.

Copies of all NCRs and any related documents and/or correspondence shall be transmitted to the organization's internal QA department or representative. 


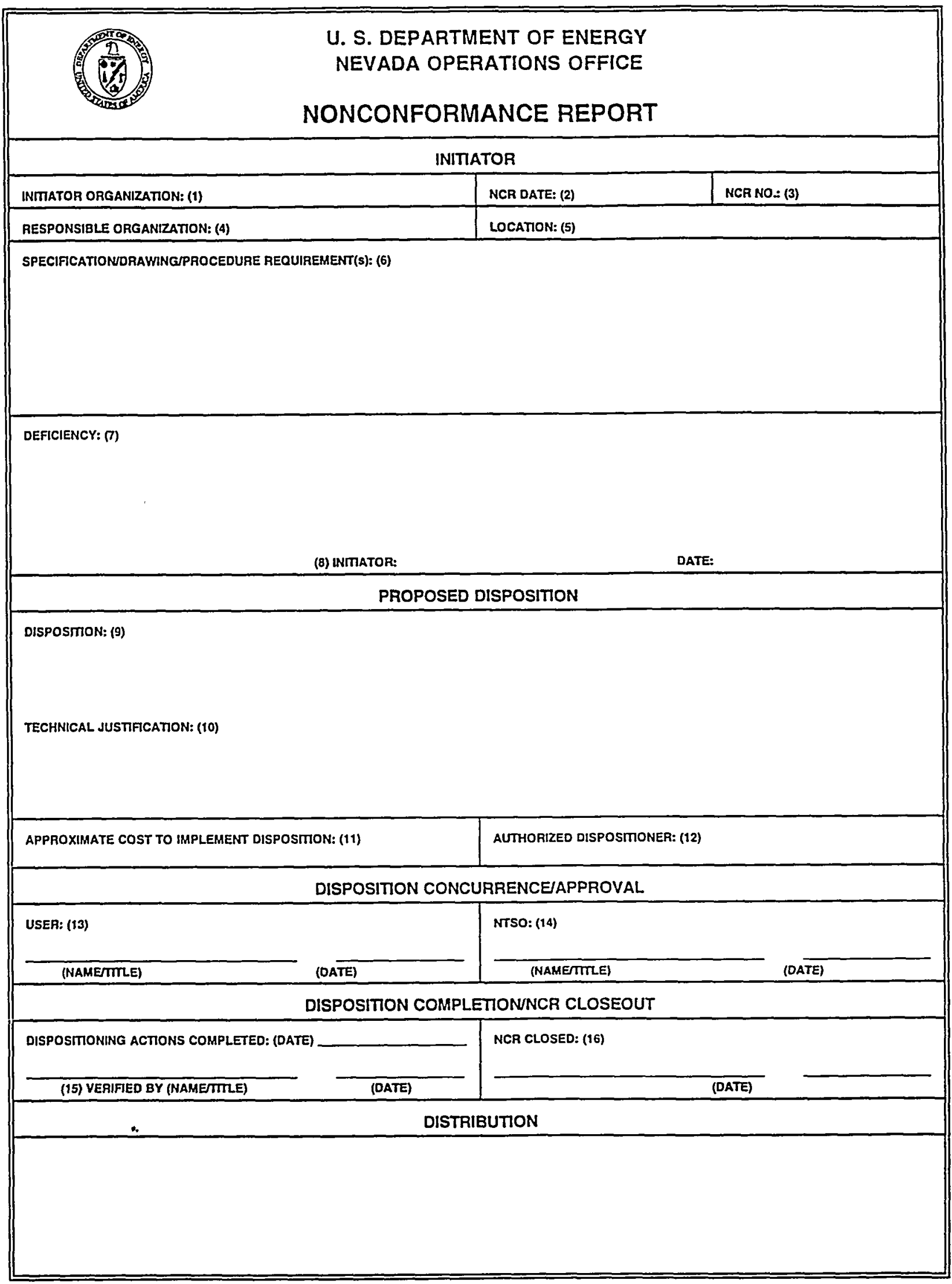




\subsubsection{Nonconformance Trends}

Subproject participants shall perform reviews and trend analyses of NCRs to identify any possible adverse trends. At a minimum. adverse trends are considered to be:

- Repetitive nonconformances for which previous corrective measures have proven ineffective

- Nonconformances that appear to be related and represent a programmatic or system breakdown or loss of confidence in the integrity or effectiveness of the item or activity

- Indication that a root cause may have generic implication to a broad group of possible deficiencies.

The reviews of NCRs shall be documented in a trend report. Adverse trends shall be brought to the attention of the appropriate contractor senior manager and the DOENV Subproject Manager. Adverse trends shall be documented and reported in a corrective action request.

\subsubsection{Corrective Action Request}

A corrective action request shall be used to identify and report significant conditions adverse to quality and to document the resolutions of such conditions. All RCRA Industrial Sites Subproject participants are responsible for the development and implementation of approved procedures to govern the corrective action request process. These procedures shall comply with the requirements of DOE Order 5700.6C.

A corrective action request shall be initiated when a significant condition adverse to quality has been identified. i.e., demonstrated by one of the following conditions:

- The existence of conditions that, if left uncorrected, may possibly compromise the quality program or degrade the quality of an item

- An identified adverse trend

- A failure to respond or resolve deficiencies identified during audits and surveillances or documented on an NCR in a timely manner

- A significant programmatic breakdown of management controls or the QA Program 
- The conduct of quality-affecting activities outside of the scope of approved QA program plans or procedures.

The aforementioned conditions shall be documented on a corrective action request, in accordance with internal procedures, and issued to the appropriate subproject management. When an external organization is involved, the corrective action request shall be transmitted via a cover letter to the DOE/NV Subproject Manager. A corrective action request status log shall be maintained for the purpose of tracking open corrective-action requests. 


\subsection{Criteria 4 - Documents and Records}

Systems and controls shall be implemented by subproject participants for identifying, preparing, reviewing, approving, revising, collecting, indexing, filing, storing, maintaining, retrieving, distributing, and disposing of pertinent quality documentation and records. These systems and controls shall be applicable to all forms of documents and records.

\subsection{Variances/Change Control}

Variances (changes or modifications) to approved data-collection plans may be necessary in order to adjust an activity to actual field conditions or to revise programmatic methods of implementing project requirements. A system shall be employed to ensure that variances are properly identified. documented, approved. and controlled. Variances shall be approved commensurate with the original document prior to implementation. Changes that impact the technical scope of the subproject. cost, or schedule shall be in accordance with the DOE/NV procedure ERD-01-003, Change Control.

\subsection{Document Review and Control}

Documents shall be reviewed, approved, and revised in accordance with prescribed processes and DOE/NV procedure ERD-01-002, Document Review and Coordination. RCRA Industrial Sites Subproject documents. and changes to documents. shall be reviewed for quality requirements, technical adequacy, completeness, and accuracy prior to their approval and issuance.

A system or process for identifying and controlling documents shall be implemented to ensure that the latest revision of a document is in use. Contractor subproject management shall be responsible for ensuring that personnel who perform work are in possession of the most current version of the documents applicable to the activities being conducted. 


\subsection{Subproject Documentation and Maintenance}

RCRA Industrial Sites Subproject documentation and data reports shall be complete and accurate to the extent that their use in a decision-making process can be legally defended. The maintenance of records shall include provisions for retention, protection, preservation, traceability, accountability, and retrievability. Maintenance of records shall be in accordance with DOE Order 1324.2A, Records Disposition. Records to be maintained include, but are not limited to, the following:

- Records of design

- Calculations

- Specifications

- Checkprints

- Procurement documents

- Procedures

- Work instructions

- Sample collection logs

- Chain-of-custody records

- Calibration and maintenance records

- Assessments

- Subproject reports. 
Resource Conservation and Recovery Act

\author{
Industrial Sites \\ Quality Assurance Project Plan
}

Part C

Performance

Nevada Environmental Restoration Project 


\subsection{Criteria 5 - Work Processes}

All activities shall be performed in accordance with approved plans and procedures.

Contractor-specific procedures shall comply with all applicable requirements of DOE Orders, procedures, and subproject planning documents. Contractors and participating organizations shall issue controlled copies of all applicable procedures to the Nevada ER Project prior to use in the RCRA Industrial Sites Subproject. All deviations from approved subproject plans and procedures shall be documented.

\subsection{Sampling Procedures}

The selection of sampling locations shall be based upon the objectives of the sampling activities. Details of specific environmental data-collection activities are discussed in the characterization and closure plans applicable to each RCRA Industrial Site. Appropriate technical methods or a scientific rationale for choosing sampling locations shall be employed. Environmental sample-collection data shall be documented on a sample collection log. Table 5-1 lists the field procedures required for work at each site.

\subsubsection{Decontamination}

To prevent cross contamination of samples, sampling equipment shall be decontaminated prior to use and between sampling locations. Decontamination activities shall be performed in accordance with approved procedures and shall be documented in a daily activity report. Precleaned sample containers shall be certified according to EPA criteria, as applicable, and the documentation of cleanliness shall be maintained in the subproject files.

Rinsate blanks shall be submitted to the analytical laboratory to assess the effectiveness of the decontamination process. If the rinsate blank results indicate possible contamination, corrective actions shall be implemented to preclude recurrence. Sample results obtained using the suspect sampling equipment shall be reviewed to determine whether analytical qualifiers should be assigned to the data. The results of the investigation shall be documented. 


\section{Table 5-1 \\ Field Procedures for Resource Conservation and Recovery Act Industrial Sites} (Page 1 of 2)

\begin{tabular}{|c|c|c|c|c|c|c|c|}
\hline Procedure & $\begin{array}{c}\text { Area } 27 \\
\text { Explosives } \\
\text { Ordnance } \\
\text { Disposal } \\
\text { Unit }\end{array}$ & $\begin{array}{c}\text { Area } 23 \\
\text { Building } \\
650 \\
\text { Leachfield }\end{array}$ & $\begin{array}{c}\text { Area } 3 \\
\text { U-3fi Waste } \\
\text { Well }\end{array}$ & $\begin{array}{c}\text { Area } 6 \\
\text { Decontam- } \\
\text { ination } \\
\text { Pond } \\
\text { Facility }\end{array}$ & $\begin{array}{l}\text { Area } 6 \\
\text { Steam- } \\
\text { Cleaning } \\
\text { Effluent } \\
\text { Ponds }\end{array}$ & $\begin{array}{c}\text { Area } 2 \\
\text { Bitcutter } \\
\text { and Post- } \\
\text { shot Shops }\end{array}$ & $\begin{array}{c}\text { Area } \\
2 U-2 b u \\
\text { Crater }\end{array}$ \\
\hline $\begin{array}{l}\text { Field Activities } \\
\text { Documentation }\end{array}$ & $x$ & $x$ & $x$ & $x$ & $x$ & $x$ & $x$ \\
\hline Chain of Custody & $x$ & $x$ & $x$ & $x$ & $x$ & $x$ & $x$ \\
\hline $\begin{array}{l}\text { Sample Handling, } \\
\text { Packagıng, } \\
\text { Shipment }\end{array}$ & $x$ & $x$ & $x$ & $x$ & $x$ & $x$ & $x$ \\
\hline $\begin{array}{l}\text { Collection of Quality } \\
\text { Control Samples }\end{array}$ & $x$ & $x$ & $x$ & $\mathrm{x}$ & $x$ & $x$ & $x$ \\
\hline $\begin{array}{l}\text { Sampling- } \\
\text { Equipment } \\
\text { Decontamination }\end{array}$ & $x$ & $x$ & $x$ & $x$ & $x$ & $x$ & $x$ \\
\hline $\begin{array}{l}\text { Personnel } \\
\text { Decontamination }\end{array}$ & $x$ & $x$ & $x$ & $x$ & $x$ & $x$ & $x$ \\
\hline $\begin{array}{l}\text { Surface-Soil } \\
\text { Sampling }\end{array}$ & $x$ & $x$ & $x$ & $x$ & $x$ & $x$ & $x$ \\
\hline $\begin{array}{l}\text { Shallow Subsurface } \\
\text { Sampling With a } \\
\text { Hand-Coring Device }\end{array}$ & $x$ & $x$ & $x$ & $x$ & $x$ & $x$ & $x$ \\
\hline $\begin{array}{l}\text { Subsurface-Soil } \\
\text { Sampling When } \\
\text { Drilling }\end{array}$ & $x$ & $x$ & $x$ & $x$ & $x$ & $x$ & $x$ \\
\hline $\begin{array}{l}\text { Sediment/Sludge } \\
\text { Sampling }\end{array}$ & & & & $x$ & $x$ & & \\
\hline $\begin{array}{l}\text { Borehole Lithology } \\
\text { Description }\end{array}$ & & $x$ & $x$ & $x$ & $x$ & $x$ & $x$ \\
\hline $\begin{array}{l}\text { Electromagnetic } \\
\text { Surveying }\end{array}$ & $x$ & $x$ & & $x$ & $x$ & & \\
\hline $\begin{array}{l}\text { Ground- Penetrating } \\
\text { Radar Survey }\end{array}$ & & $x$ & & & & & \\
\hline $\begin{array}{l}\text { Radioactive Waste } \\
\text { Management } \\
\text { Guidance }\end{array}$ & $x$ & $x$ & $x$ & $x$ & $x$ & $x$ & $x$ \\
\hline $\begin{array}{l}\text { Control of } \\
\text { Hazardous Materials }\end{array}$ & $x$ & $x$ & $x$ & $x$ & $x$ & $x$ & $x$ \\
\hline Waste Packaging & $x$ & $\mathrm{x}$ & $x$ & $\mathrm{x}$ & $x$ & $x$ & $x$ \\
\hline
\end{tabular}

$X=$ Procedure required.

Blank cells indicate no procedure required. 
Table 5-1

\section{Field Procedures for \\ Resource Conservation and Recovery Act Industrial Sites}

(Page 2 of 2)

\begin{tabular}{|c|c|c|c|c|c|c|c|}
\hline Procedure & $\begin{array}{c}\text { Area } 27 \\
\text { Explosives } \\
\text { Ordnance } \\
\text { Disposal } \\
\text { Unit }\end{array}$ & $\begin{array}{c}\text { Area } 23 \\
\text { Building } \\
650 \\
\text { Leachfield }\end{array}$ & $\begin{array}{c}\text { Area } 3 \\
\text { U-3ft Waste } \\
\text { Well }\end{array}$ & $\begin{array}{l}\text { Area } 6 \\
\text { Decontam- } \\
\text { ination } \\
\text { Pond } \\
\text { Facility }\end{array}$ & $\begin{array}{l}\text { Area } 6 \\
\text { Steam- } \\
\text { Cleaning } \\
\text { Effluent } \\
\text { Ponds }\end{array}$ & $\begin{array}{c}\text { Area } 2 \\
\text { Bitcutter } \\
\text { and Post- } \\
\text { shot Shops }\end{array}$ & $\begin{array}{l}\text { Area } \\
\text { 2U-2bu } \\
\text { Crater }\end{array}$ \\
\hline $\begin{array}{l}\text { Shipment of Waste } \\
\text { Under NVO-325 } \\
\text { Requirements }\end{array}$ & $x$ & $x$ & $x$ & $x$ & $x$ & $x$ & $x$ \\
\hline $\begin{array}{l}\text { Waste Certification } \\
\text { Official Procedure }\end{array}$ & $x$ & $x$ & $x$ & $x$ & $x$ & $x$ & $x$ \\
\hline $\begin{array}{l}\text { Hazardous Waste } \\
\text { Management }\end{array}$ & $x$ & $\bar{x}$ & $x$ & $x$ & $x$ & $x$ & $x$ \\
\hline $\begin{array}{l}\text { Determination of } \\
\text { Mixed Waste } \\
\text { Shipping Name }\end{array}$ & $x$ & $x$ & $x$ & $x$ & $x$ & $x$ & $x$ \\
\hline $\begin{array}{l}\text { Determination of } \\
\text { Low-Level Waste } \\
\text { Shipping Name }\end{array}$ & $x$ & $x$ & $x$ & $x$ & $x$ & $x$ & $x$ \\
\hline $\begin{array}{l}\text { Nonhazardous } \\
\text { Waste Management }\end{array}$ & $x$ & $x$ & $x$ & $x$ & $x$ & $x$ & $x$ \\
\hline Field GC Screening & & $x$ & $x$ & $x$ & $x$ & $x$ & $x$ \\
\hline $\begin{array}{l}\text { Sampling Vapor in } \\
\text { Vadose Zone } \\
\text { Monitoring Wells }\end{array}$ & & & $x$ & & & & \\
\hline Pressure Testing & & $x$ & & $x$ & $x$ & & \\
\hline $\begin{array}{l}\text { Radiological } \\
\text { Screening }\end{array}$ & $x$ & $x$ & $x$ & $x$ & $x$ & $x$ & $x$ \\
\hline Drilling Operations & $x$ & $x$ & $x$ & $x$ & $x$ & $x$ & $x$ \\
\hline $\begin{array}{l}\text { Downhole Neutron } \\
\text { Logging }\end{array}$ & $x$ & $x$ & $x$ & $x$ & $x$ & $x$ & $x$ \\
\hline $\begin{array}{l}\text { Drill Rig/Backhoe } \\
\text { Decontamination }\end{array}$ & $x$ & $x$ & $x$ & $x$ & $x$ & $x$ & $x$ \\
\hline $\begin{array}{l}\text { Site Access } \\
\text { Procedures }\end{array}$ & $x$ & $x$ & $x$ & $x$ & $x$ & $x$ & $x$ \\
\hline Video Logging & & & $x$ & & & & \\
\hline Angle Borings & & & $x$ & & & & $x$ \\
\hline $\begin{array}{l}\text { Directional Survey of } \\
\text { Angle Borings }\end{array}$ & & & $x$ & & & & $x$ \\
\hline $\begin{array}{l}\text { Seismic } \\
\text { Tomography }\end{array}$ & & & $x$ & & & & \\
\hline
\end{tabular}

$X=$ Procedure required.

Blank cells indicate no procedure required. 


\subsubsection{Sample Handling and Preservation}

Proper sample handling shall be achieved by selecting appropriate sample containers. preservation procedures, and holding times for specific analyses. Sample containers shall be obtained and, as appropriate, certified clean, per EPA protocol, from an approved laboratory and shall remain sealed until ready for use. Sample container materials, preservation techniques, sample volumes, and holding times for required analyses can be found in Tables 5-2, 5-3, 5-4, and 5-5.

Both site characterization/closure verification samples and waste characterization samples may be analyzed for either total chemical parameters for Toxicity Characteristic Leaching Procedure (TCLP) analytes, in accordance with the site-specific closure plan. For total chemical parameter analyses, the limits in Tables 5-2 and 5-3 shall apply; for TCLP analyses, the limits in Table 5-4 shall apply. Waste characterization samples shall also be analyzed for radiological parameters: the limits in Table 5-5 shall apply for these samples.

\subsubsection{Field Documentation}

Field documentation shall be of sufficient detail to facilitate the reconstruction of field activities. Field personnel shall document activities on a daily activity report or log. Entries in the log shall be made in indelible ink and shall include the following:

- The subproject name

- The date and start time of each field activity

- Names and affiliations of field personnel

- The equipment used, including identification number

- A general description of the day's field activities. showing the sequence of events

- Problems encountered

- Changes or modifications to the approved sample-collection plan

- Nonconformances and any corrective actions taken

- Weather conditions

- Field-equipment calibration data

- Field measurements or tests performed

- References to associated forms for details of each activity conducted

- The signature of the individual completing the report.

Subproject management or a designee shall review the field-generated records for completeness and accuracy. This review shall be documented by an initial and date. Reviewed records shall be maintained in the project files. 
는웅융

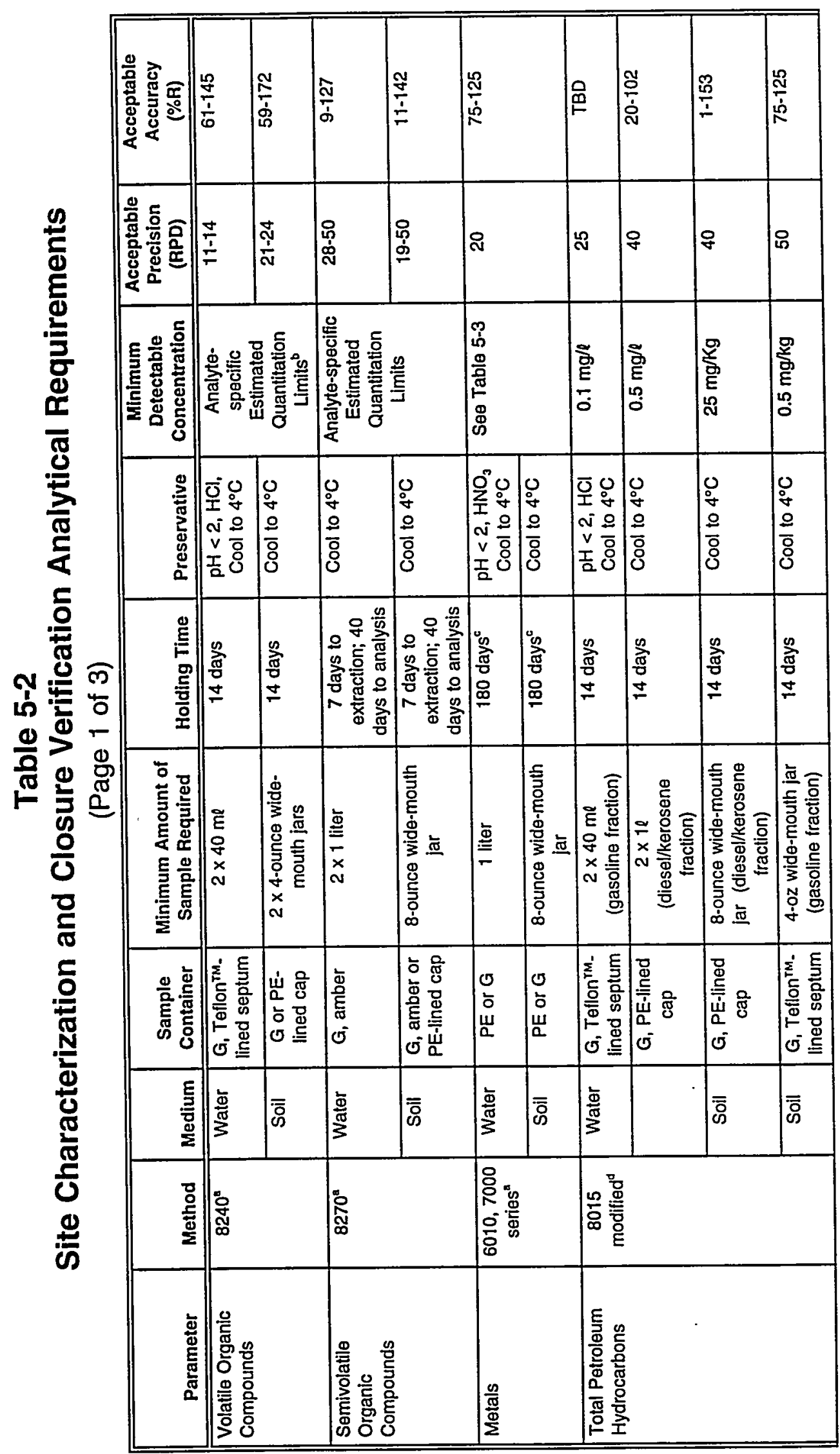

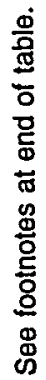




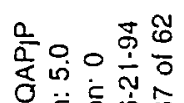

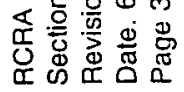

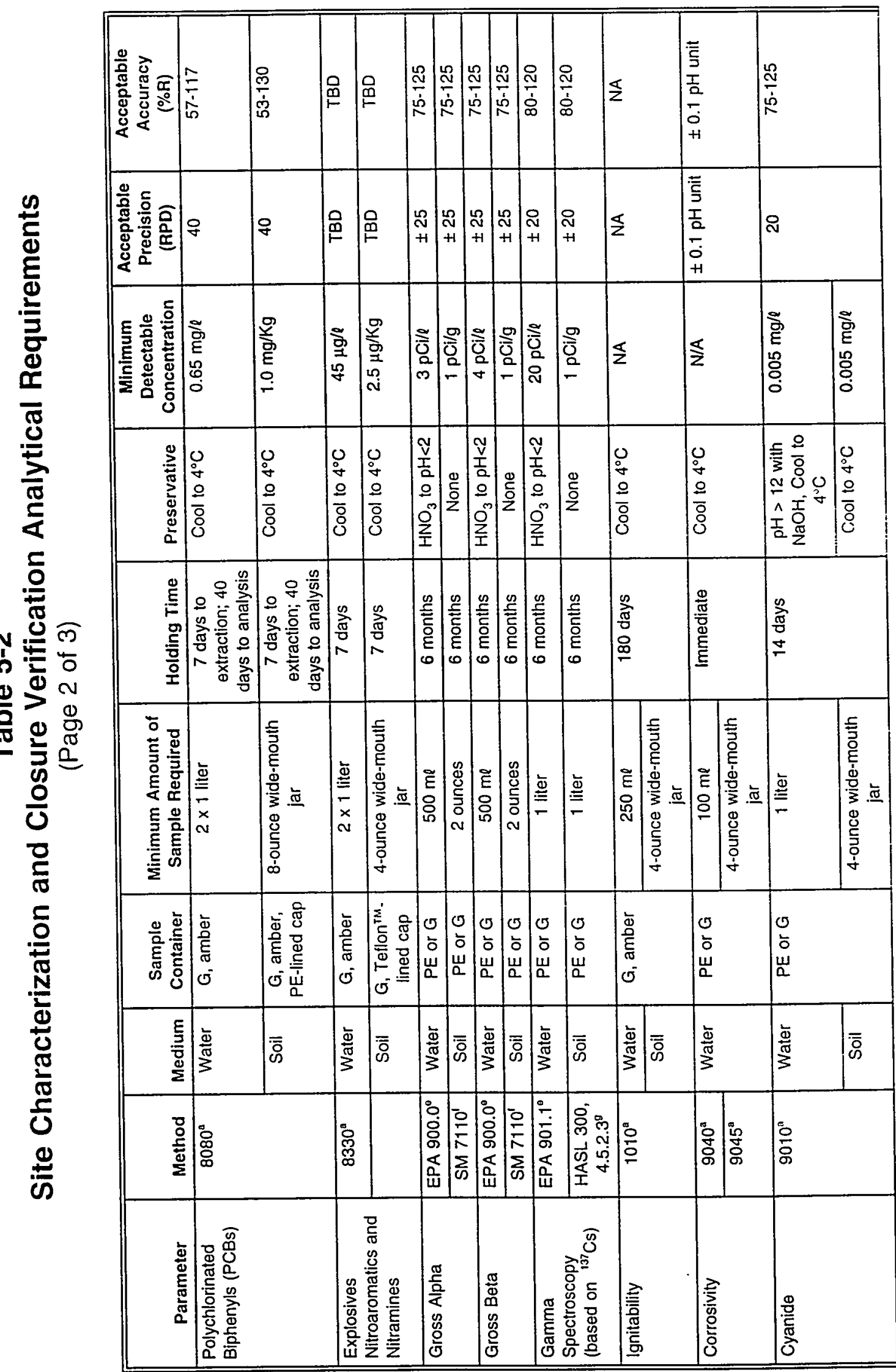

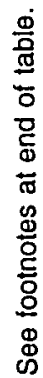




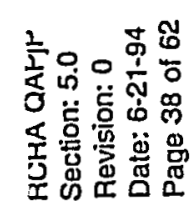

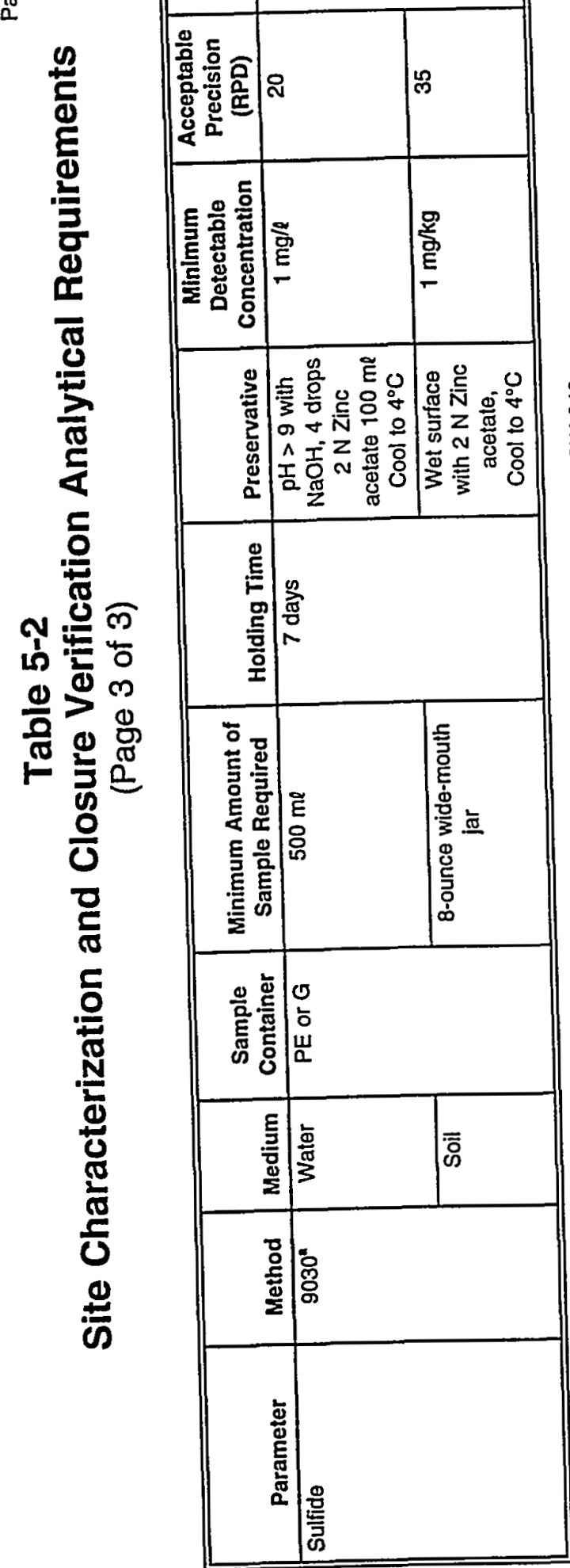

亭

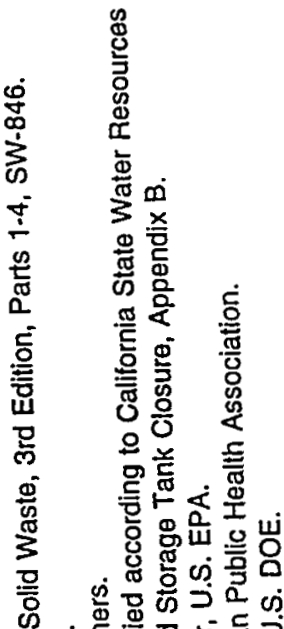

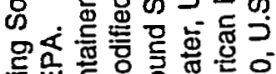

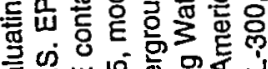

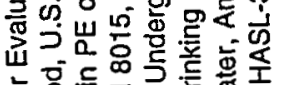

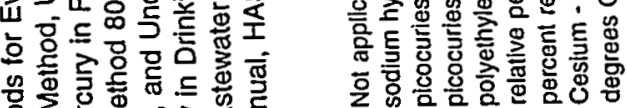
옹

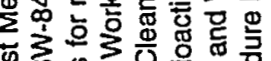

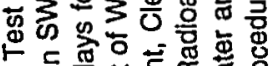

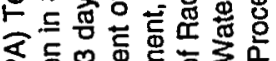

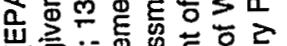

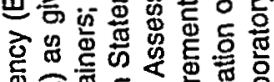

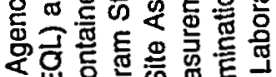

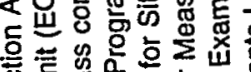

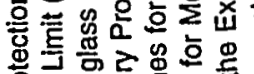

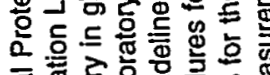

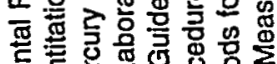

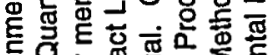

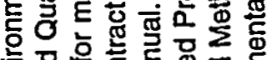

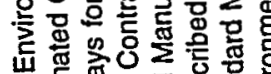

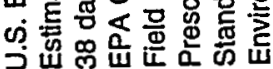
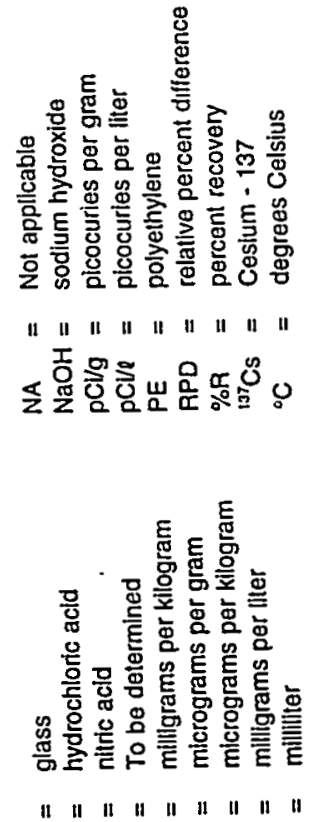

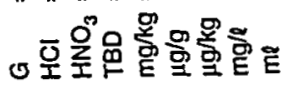




\section{Table 5-3}

\section{Minimum Detectable Concentrations for Metals}

\begin{tabular}{|c|c|c||}
\hline Element & $\begin{array}{c}\text { Water } \\
\text { micrograms/iter }\end{array}$ & $\begin{array}{c}\text { Soil } \\
\text { milligrams/kilogram }\end{array}$ \\
\hline Antimony & 60 & 6 \\
\hline Arsenic & 3 & .3 \\
\hline Barium & 200 & 20 \\
\hline Beryllium & 5 & 0.5 \\
\hline Cadmium & 5 & 0.5 \\
\hline Chromium $^{\mathrm{a}}$ & 10 & 1 \\
\hline Cobalt & 50 & 5 \\
\hline Copper & 25 & 2.5 \\
\hline Lead & 50 & 5 \\
\hline Mercury & & 0.1 \\
\hline Nickel & 0.2 & 4 \\
\hline Selenium & & .3 \\
\hline Silver & 40 & 1 \\
\hline Thallium & 3 & .3 \\
\hline Tin & 10 & 20 \\
\hline Vanadium & 3 & 5 \\
\hline Zinc & 200 & 2 \\
\hline
\end{tabular}

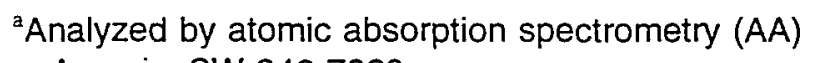

Arsenic: SW-846 7060

Mercury: SW-846 7470

Selenium: SW-846 7740

Thallium: SW-846 7841

All other elements analyzed by inductively coupled plasma-atomic emission spectrometry (ICP) 


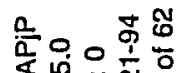

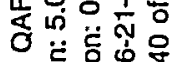

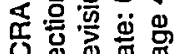

议

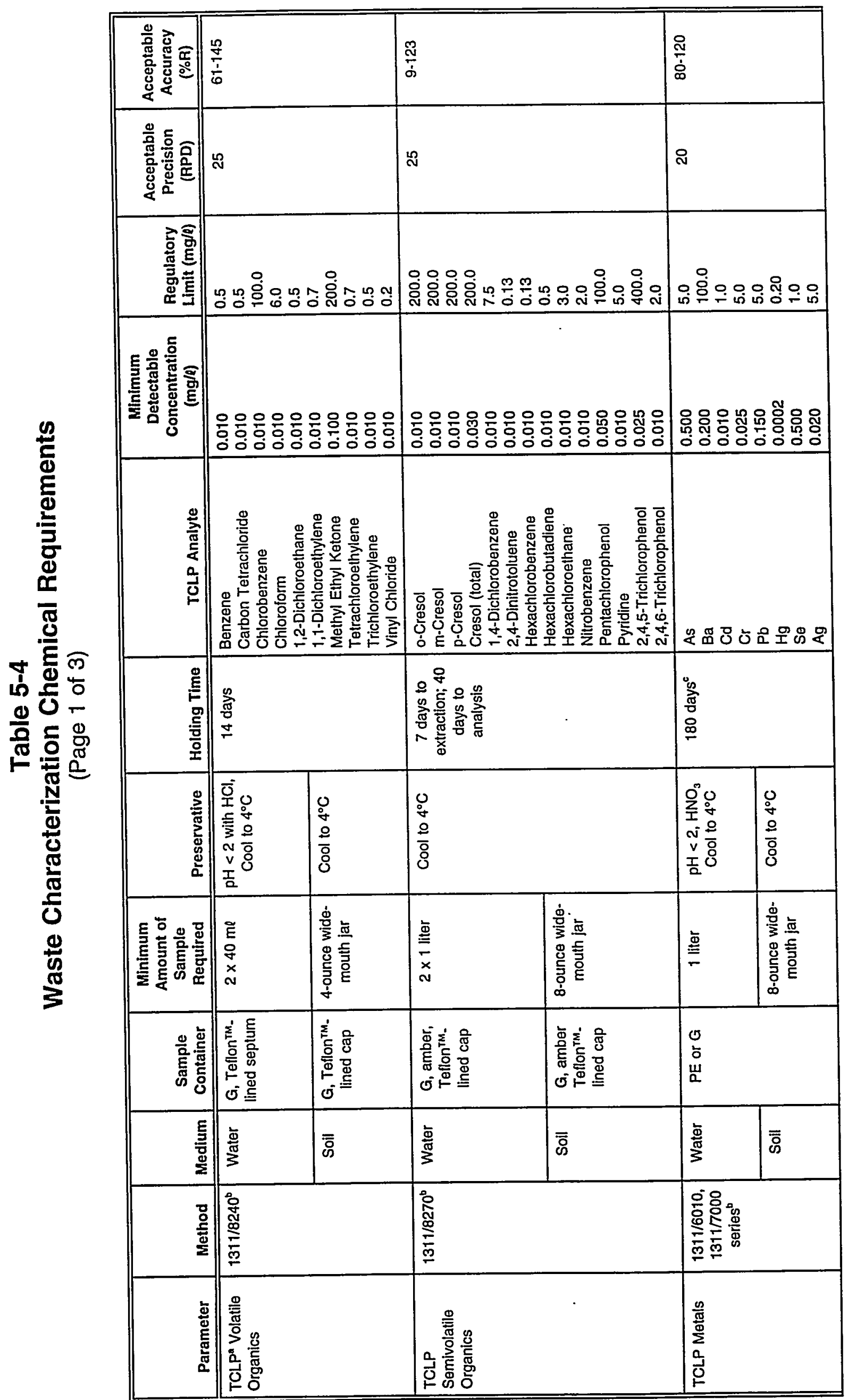

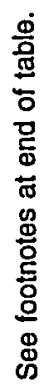




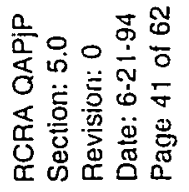

\begin{tabular}{|c|c|c|c|c|c|c|c|c|c|c|}
\hline 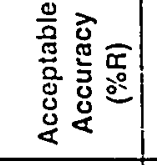 & \multicolumn{2}{|l|}{$\bar{m}$} & \multicolumn{2}{|l|}{$\frac{\mathscr{N}}{\dot{\sigma}}$} & \multicolumn{2}{|l|}{$\frac{\pi}{z}$} & \multicolumn{2}{|c|}{ 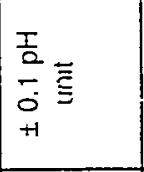 } & \multicolumn{2}{|l|}{$\frac{\stackrel{\stackrel{N}{N}}{\dot{D}}}{\stackrel{\text { r }}{r}}$} \\
\hline 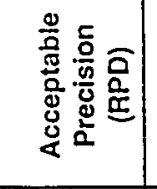 & ㅇ & & ల్లి & & $\mathbb{z}$ & & 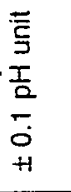 & & 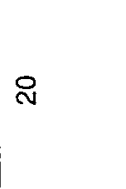 & \\
\hline 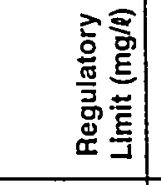 & \multicolumn{2}{|c|}{ 象 } & \multicolumn{2}{|l|}{$\stackrel{\circ}{\circ} \stackrel{\circ}{-}$} & \multicolumn{2}{|c|}{ 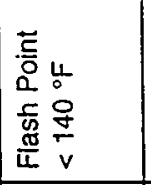 } & \multicolumn{2}{|c|}{ 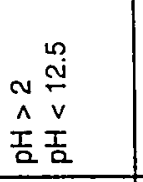 } & \multicolumn{2}{|l|}{$\sum$} \\
\hline 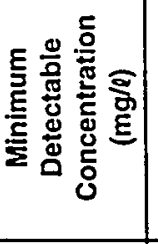 & \multicolumn{2}{|c|}{ 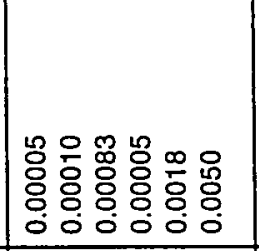 } & \multicolumn{2}{|l|}{ 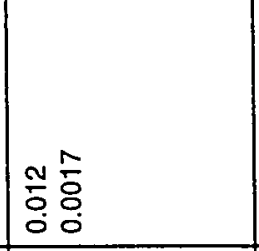 } & \multicolumn{2}{|l|}{$\Sigma$} & \multicolumn{2}{|l|}{$\Sigma$} & $\begin{array}{l}\text { ¿ } \\
0 \\
\end{array}$ & 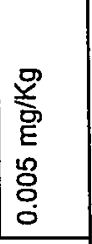 \\
\hline 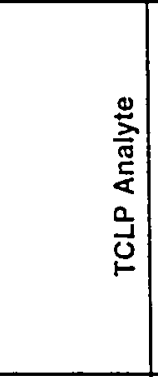 & \multicolumn{2}{|c|}{ 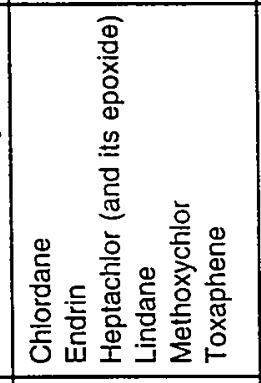 } & \multicolumn{2}{|l|}{ 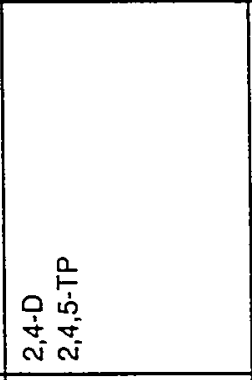 } & \multicolumn{2}{|l|}{$\Sigma$} & \multicolumn{2}{|l|}{$\Sigma$} & \multicolumn{2}{|l|}{$\Sigma$} \\
\hline 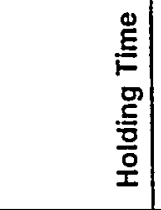 & \multicolumn{2}{|c|}{ 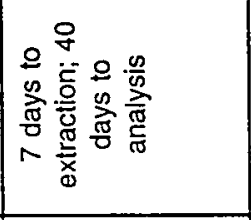 } & \multicolumn{2}{|c|}{ 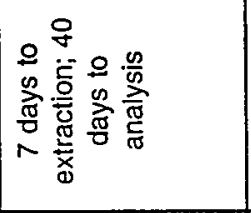 } & \multicolumn{2}{|l|}{$\begin{array}{l}0 \\
0 \\
0 \\
0 \\
0 \\
0\end{array}$} & \multicolumn{2}{|l|}{ 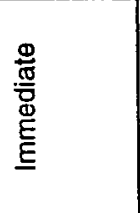 } & \multicolumn{2}{|l|}{ 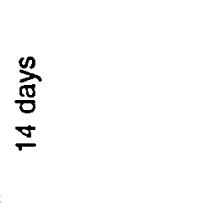 } \\
\hline 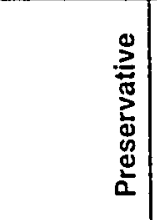 & \multicolumn{2}{|l|}{$\begin{array}{l}0 \\
0 \\
\vdots \\
0 \\
0 \\
0 \\
0 \\
0\end{array}$} & \multicolumn{2}{|l|}{$\mid \begin{array}{l}0 \\
0 \\
\dot{8} \\
0 \\
\overline{0} \\
0 \\
0\end{array}$} & \multicolumn{2}{|l|}{$\mid \begin{array}{l}0 \\
\vdots \\
\dot{8} \\
\stackrel{2}{8} \\
\overline{8} \\
0\end{array}$} & \multicolumn{2}{|l|}{$\mid \begin{array}{l}0 \\
\dot{0} \\
\dot{0} \\
\frac{0}{0} \\
0 \\
0\end{array}$} & 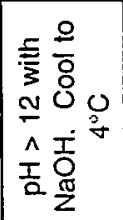 & $\begin{array}{l}0 \\
\stackrel{0}{8} \\
\stackrel{0}{0} \\
\text { o }\end{array}$ \\
\hline 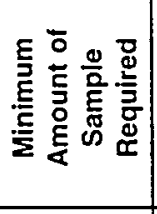 & $\stackrel{\stackrel{\Phi ळ}{=}}{=}$ & 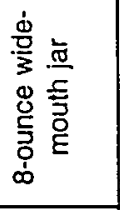 & $\stackrel{\stackrel{⿹}{\leftrightarrows}}{=}$ & 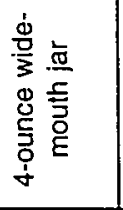 & हి & 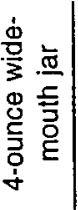 & है & 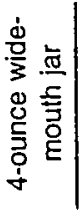 & 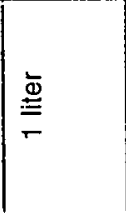 & 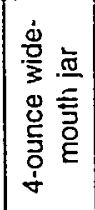 \\
\hline 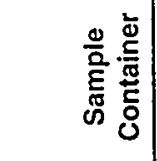 & 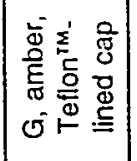 & 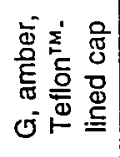 & 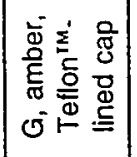 & 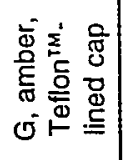 & 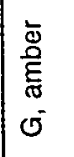 & & $\begin{array}{l}0 \\
\vdots \\
w \\
a\end{array}$ & & $\begin{array}{l}0 \\
\vdots \\
w \\
\alpha\end{array}$ & \\
\hline $\begin{array}{l}\underline{\underline{z}} \\
\overline{\bar{z}} \\
\mathbf{\mathrm { \omega }} \\
\mathrm{z}\end{array}$ & $\underbrace{\frac{\bar{g}}{w}}$ & $\overline{\overline{\bar{o}}}$ & $\frac{\frac{5}{5}}{\stackrel{5}{3}}$ & $\overline{\bar{\delta}}$ & 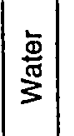 & 容 & 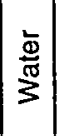 & $\overline{\overline{\bar{\delta}}}$ & $\frac{5}{\frac{5}{\pi}}$ & 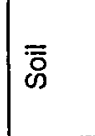 \\
\hline $\begin{array}{l}\overline{0} \\
\frac{0}{0} \\
\frac{\mathbf{d}}{2}\end{array}$ & 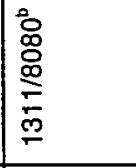 & & $\frac{\stackrel{0}{0}}{\frac{0}{0}}$ & & 웅 & & $\begin{array}{l}\text { : } \\
\text { 훟 } \\
\text { के }\end{array}$ & 占 & 웅 & \\
\hline 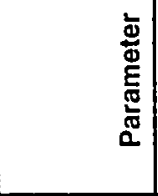 & 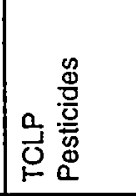 & & 步 & & 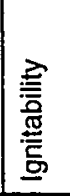 & & 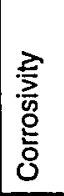 & & 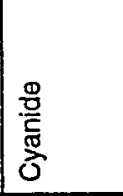 & \\
\hline
\end{tabular}




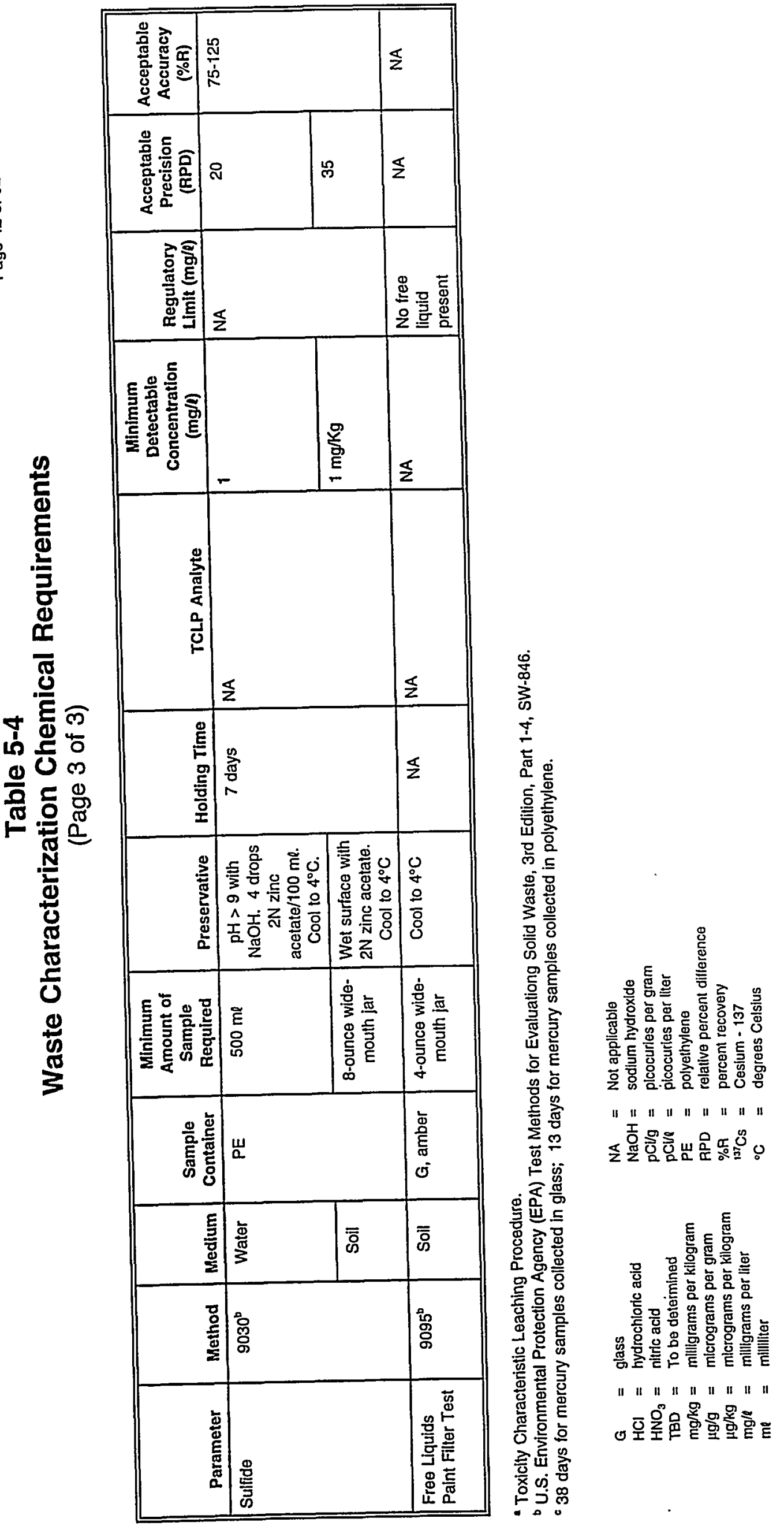




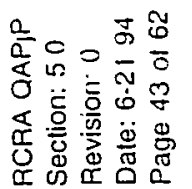

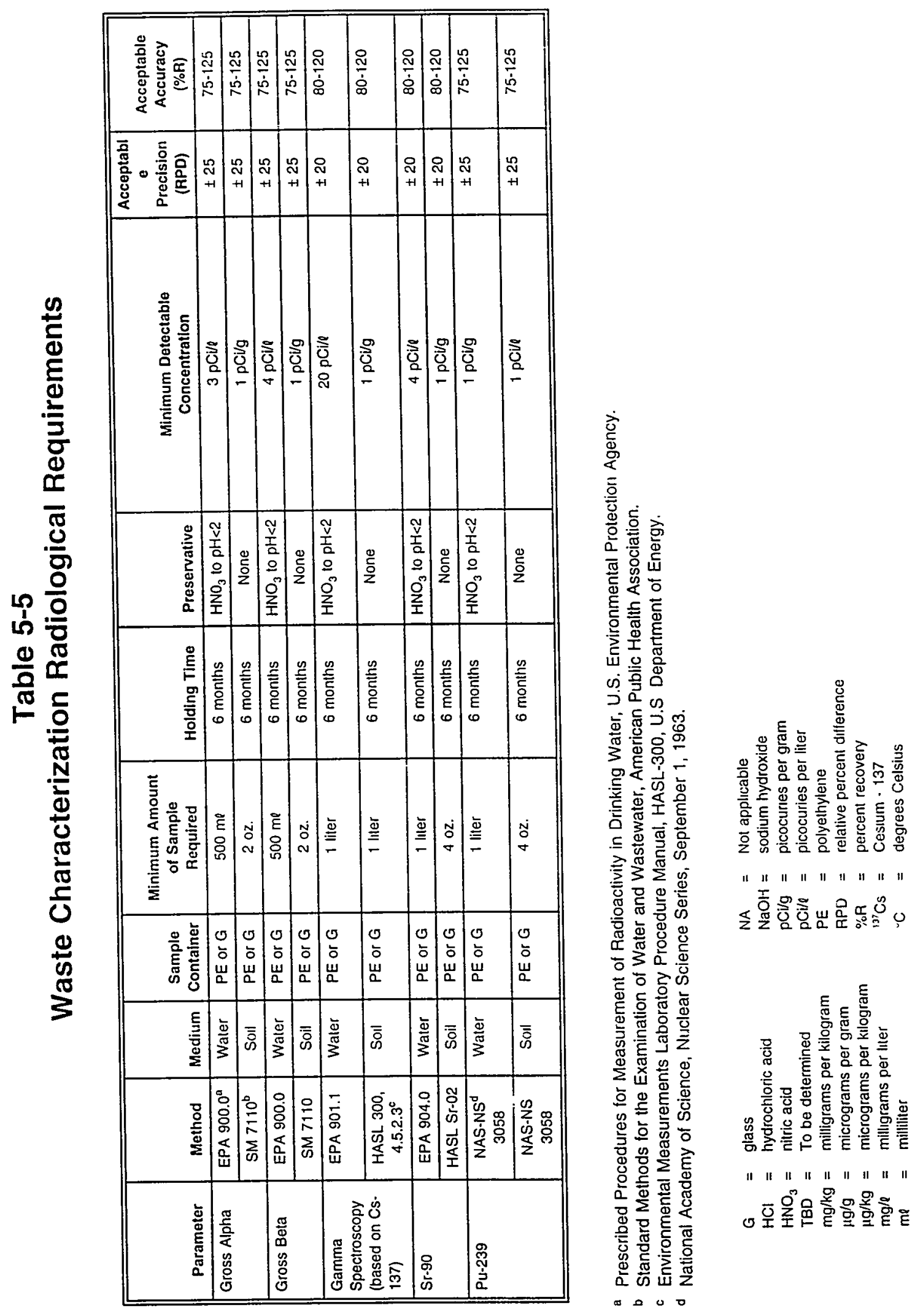




\subsubsection{Photographic Documentation}

With the approval of the DOE/NV and in accordance with NTS requirements, photographs shall be taken of characterization and closure activities. Any photographs taken shall include an information sign in the photograph, which shall identify the date, subproject name, and site number or other identifying number. Photographs shall be documented on the daily activity report and processed and stored in accordance with DOE/NV security procedures.

\subsection{Sample Custody}

Maintaining chain of custody demonstrates through objective evidence that samples were obtained from the locations stated in the analytical request and that they reached the laboratory without alteration and in proper condition. A sample is considered to be in custody if it is in a:

- Person's actual possession

- Person's unobstructed view, after being in the person's physical possession

- Secured area to prevent tampering, after having been in physical possession

- Designated secured area, restricted to authorized personnel only.

Custody is initiated by field personnel at the sampling location and is completed by laboratory personnel upon final disposition of the sample. Subproject management shall monitor the sampling event(s) to ensure that custody procedures and records are being properly implemented. Without exception, sample custody shall be maintained for all samples.

\subsubsection{Chain-of-Custody/Analysis Request Form}

Each sample shall be assigned a unique identification number that is recorded on both the individual sample label and the chain-of-custody form. Field teams shall prepare chain of custody/analysis request (COC/AR) forms for samples collected during field activities. The COC/AR form shall accompany the samples during handling and shipment and identify the sample custodian. The COC/AR form shall include the following information:

- The unique sample number and sample description

- The subproject name and number

- The date and time (military) of the sample collection

- The container type, sample volume, and preservation used 
- The analysis requested

- Special instructions to the laboratory, including sample handling and disposition

- Laboratory destination and contact

- Names of sampling personnel

- The signature of a sampling team member

- The name and phone number of the subproject contact

- The name of carrier and the waybill number (if applicable)

- Chain-of-custody control numbers

- Possible hazard identification.

Each individual who collects a sample is responsible for sample custody until the sample is relinquished to another individual via the COC/AR form. Whenever samples are transferred to a new sample custodian, the new custodian shall sign his or her name and the company name and note the time and date that the transfer occurred.

If field samples are split for shipment to separate laboratories or samples are composited, a new COC/AR form must be generated. Sample information on the original COC/AR form shall not be deleted, marked out, or obscured in any way. The original and the new COC/AR forms must cross-reference each other using the unique COC/AR form number. Copies of the original field COC/AR form shall be attached to the new form. One copy of the COC/AR form shall be retained by the field sampling personnel for tracking purposes.

\subsubsection{Sample Labels and Identification}

Identification and traceability of samples collected as part of a data-collection task are critical to the success of the RCRA Industrial Sites Subproject. Sample labels shall be affixed to containers in a manner that does not obscure any data preprinted on the containers. Unique sample numbers and other sampling information shall be printed on the labels using indelible ink. All information and data for a sample are keyed to each sample's unique sample number. The sample label shall contain the following required information:

- The subproject name

- A unique sample number

- The sample location

- The sampling date and time

- The initials of the individual collecting the sample (initial custodian of the sample)

- Preservation or conditioning of the sample. 
Each sample number shall be indicated on both the container and field data/sample collection forms. For samples requiring multiple containers, the same sample identification numbers are required on each container.

\subsubsection{Custody Seals}

Samples shall be placed in containers and sealed with custody seals. Prior to being relinquished, each sample container shall be sealed over and/or around the cap with custody tape. Custody seals shall be initialed and dated by the sample custodian.

\subsubsection{Sample Packaging and Shipping}

Upon completion of sampling, labeling, and custody sealing, each sample shall be placed in a sealable plastic bag, transferred to a cooler, packed with ice or.its equivalent, and protected from breakage by using shock-absorbent packing material. Approved procedures shall be in place for the packaging and shipping of samples that comply with U.S. Department of Transportation regulations, DOE Orders and procedures, and NTS SOPs.

Prior to transport to a laboratory, samples collected at the NTS must be radiologically screened and have a Material Clearance Tag (Green) Form RE-1581 affixed in accordance with Reynolds Electrical \& Engineering Co., Inc. (REECo) procedure AABBA.D.05.05.06. Samples to be taken off the NTS must then be taken to the REECo Radioactive Material Control office in Mercury, Nevada, for property removal authorization.

Samples destined for a laboratory off the NTS shall be sent by an overnight delivery service to the laboratory stipulated in the site plans in accordance with EPA guidance. Copies of the waybill shall be retained in the closure records. The original COC/AR form shall be returned to project management after final sample disposition and shall become a permanent part of the project file.

\subsection{Analytical Procedures}

Analytical support laboratories are encouraged to review all associated RCRA Industrial Sites Subproject plans to obtain background information and sampling strategy information that may be useful for predicting potential impacts to analytical operations and sample loading. 
Each laboratory performing analyses for the RCRA Industrial Sites Subproject shall have approved written procedures for each required analysis. Deviations from the procedures shall be documented and filed in the contractor subproject files.

\subsubsection{EPA Analytical Levels}

Analytical requirements for methods and documentation are broken into analytical levels. The EPA CLP levels are used for this purpose. However, whenever other than Level IV is used, specific requirements for QC and documentation shall be developed for the laboratory to ensure adequate records for validation. Analytical levels are defined as follows:

- Level I: Field screening or analyses using portable instruments. Results are often not compound-specific and quantitative, but are available immediately.

- Level II: Field analyses using more sophisticated, portable analytical instruments. In some cases, the instruments may be set up in an on-site mobile laboratory. The quality of data generated depends on the use of suitable calibration standards, reference materials, sample preparation equipment, and the training level of the operator. Results are available immediately or within several hours.

- Level III: All analyses performed in an off-site analytical laboratory using methods other than procedures (e.g., SW-846 methods). The laboratory may or may not be a CLP/RAS laboratory.

- Level IV: All analyses performed in an off-site laboratory following CLP/RAS procedures. Level IV is characterized by rigorous QA/QC protocols and documentation.

- Level V: CLP Special Analytical Services or analyses by nonstandard methods. All analyses are performed in an off-site analytical laboratory, which may or may not be a CLP laboratory. Method development or method modification may be required for specific constituents or detection limits.

Table 5-6 illustrates the data uses, types of analyses, limitations, and data quality associated with each analytical level. All samples collected site characterization, closure verification, and waste characterization shall be analyzed at Level III using modified CLP reporting forms that meet the requirements specified in NVO-325 (Rev 1) 1992. 
Table 5-6

Summary of Analytical Levels Appropriate to Data Uses

\begin{tabular}{|c|c|c|c|c|}
\hline $\begin{array}{l}\text { Analytical } \\
\text { Level }\end{array}$ & Data Uses & Types of Analyses & Limitations & Data Quality \\
\hline Level I & $\begin{array}{l}\text { Site characterization and } \\
\text { monitoring during } \\
\text { implementation }\end{array}$ & $\begin{array}{l}\text { Total organic/inorganic } \\
\text { vapor detection using } \\
\text { portable instruments }\end{array}$ & $\begin{array}{l}\text { Instruments respond to } \\
\text { naturally-occurring } \\
\text { compounds }\end{array}$ & $\begin{array}{l}\text { If instruments are calibrated } \\
\text { and data are interpreted } \\
\text { correctly, can provide } \\
\text { indication of contamination }\end{array}$ \\
\hline Level II & $\begin{array}{l}\text { Site characterization, } \\
\text { evaluation of alternatives, } \\
\text { engineering design, and } \\
\text { monitoring dunng } \\
\text { implementation }\end{array}$ & $\begin{array}{l}\text { - Variety of organics by } \\
\text { GC/MS } \\
\mathrm{AA}^{\mathrm{b}}, \mathrm{XRF}^{\mathrm{a}} \text { inorganics by } \\
\text { - Tentative identification; } \\
\text { analyte-specific } \\
\text { - Detection limits vary } \\
\text { from low ppm } \\
\mathrm{ppb}^{\mathrm{a}} \text { to low }\end{array}$ & $\begin{array}{l}\text { - Tentative } \\
\text { identification } \\
\text { - Techniques/ } \\
\text { instruments limited } \\
\text { mostly to volatiles, } \\
\text { metals }\end{array}$ & $\begin{array}{l}\text { - Dependent on QAQC' } \\
\text { steps employed } \\
\text { - Data typically reported in } \\
\text { concentration ranges }\end{array}$ \\
\hline Level III & $\begin{array}{l}\text { Risk assessment, site } \\
\text { characterization, evaluation } \\
\text { of alternatives. engineering } \\
\text { design, and monitoring } \\
\text { during implementation }\end{array}$ & $\begin{array}{l}\text { Organic/inorganics using } \\
\text { EPA }^{g} \text { procedures other } \\
\text { than CLP } \text {, can be } \\
\text { analyte-specific } \\
\text { - RCRA' characteristic } \\
\text { tests }\end{array}$ & $\begin{array}{l}\text { - Tentative } \\
\text { identification in some } \\
\text { cases } \\
\text { - Can provide data of } \\
\text { same quality as } \\
\text { Level IV, NS' }\end{array}$ & $\begin{array}{l}\text { - Detection limits similar to } \\
\text { CLP } \\
\text { - Less rigorous QAVQC } \\
\text { - Goal is data of known } \\
\text { quality }\end{array}$ \\
\hline Level IV & $\begin{array}{l}\text { Risk assessment, } \\
\text { evaluation of alternatives, } \\
\text { engineering design }\end{array}$ & $\begin{array}{l}\text { HSL } L^{k} \text { organics/inorganics } \\
\text { by GC/MS, AA, ICP' }\end{array}$ & $\begin{array}{l}\text { - Tentative } \\
\text { identification of } \\
\text { non-HSL parameters } \\
\text { - Some time may be } \\
\text { required for } \\
\text { validation of } \\
\text { packages }\end{array}$ & $\begin{array}{l}\text { - Rigorous QAVQC } \\
\text { Provides rigorous } \\
\text { documentation suitable for } \\
\text { full validation }\end{array}$ \\
\hline Level V & Risk assessment & $\begin{array}{l}\text { - Nonconventional } \\
\text { parameters } \\
\text { - Method-specific } \\
\text { detection limits } \\
\text { - Modification of existing } \\
\text { methods } \\
\text { - Title } 40 \text { CFR Part 261, } \\
\text { Appendix VIII } \\
\text { parameters }\end{array}$ & $\begin{array}{l}\text { - May require method } \\
\text { development/ } \\
\text { modification } \\
\text { - Mechanism to odtain } \\
\text { services requires } \\
\text { special lead time }\end{array}$ & Method-specific \\
\hline
\end{tabular}

${ }^{a}$ gas chromatography/mass spectrometry

atomic absorption

${ }^{c} \mathrm{x}$-ray fluorescence

a parts per million

parts per billion

' quality assurance and quality control
${ }^{g}$ U.S. Environmental Protection Agency

${ }^{\mathrm{h}}$ Contract Laboratory Program

' Resource Conservation and Recovery Act

I nonstandard

${ }^{k}$ Hazardous Substance List

' inductively coupled plasma atomic emission spectroscopy 


\subsubsection{Analytical Methods}

Analytical methods shall follow EPA Test Methods for Evaluating Solid Waste. 3rd Edition. Parts 1-4 (SW-846), when appropriate. For some radiometric analyses where no EPAapproved methods exist, laboratories shall follow Standard Methods for the Examination of Water and Wastewater or Environmental Measurements Laboratory Procedures Manual, HASL-300 as indicated on Tables 5-2 and 5-4. The reporting format selected for both data types requires the use of modified CLP report forms similar to those specified in NVO-325 (Rev.1).

\subsection{Calibration and Preventive Maintenance}

A system of calibration and preventive maintenance shall be employed by subproject participants to ensure the proper operation of M\&TE. Reference standards of the correct type, range, and acceptable uncertainty shall be used for collecting data consistent with the project objectives. All RCRA Industrial Sites Subproject participants are responsible for implementing calibration and preventive maintenance programs for field and laboratory M\&TE.

\subsubsection{Calibration}

M\&TE that requires calibration shall be uniquely identified by the manufacturer's serial number or a suitable assigned number. Whenever possible, the M\&TE identification number will be permanently marked on the equipment. The calibration status shall be identified on labels or stickers affixed to the instrument. These labels shall include the current calibration date and the next calibration due date. When it is impractical to label M\&TE due to size or configuration, calibration records traceable to the M\&TE must include this information and be kept in close proximity to the equipment.

M\&TE shall be calibrated prior to use for RCRA Industrial Sites Subproject activities and at prescribed intervals thereafter. During M\&TE usage, operational checks of the equipment shall be performed to verify the equipment's continued accuracy and operational function. Calibrations of M\&TE shall be performed by trained and qualified personnel, approved external agencies, or the equipment manufacturer. Calibration shall be performed in accordance with approved procedures or the manufacturer's recommendations. All periodic 
and operational calibrations shall be documented and maintained in the project files. These record files shall include, as applicable, M\&TE calibration certificates and reference standard certifications. Calibration controls are not required for rulers, tapes, levels, and similar devices if normal commercial M\&TE provides adequate accuracy.

\subsubsection{Calibration Frequency}

M\&TE shall be calibrated at prescribed intervals. The frequency of periodic calibrations shall be based on the manufacturer's recommendations, national standards of practice, equipment type and characteristics, and past experience. Operational calibrations and/or source-response checks shall be performed on the appropriate M\&TE prior to the start of work and reestablished at prescribed intervals that have been predetermined and are instrument-specific. During use, calibration and/or response checks shall be performed and documented on the appropriate field form to verify that the M\&TE functions correctly.

\subsubsection{Reference Standards and Equipment}

Calibration reference standards and equipment shall have known relationships to the National Institute of Standards and Technology (NIST) or other nationally recognized standards. If a national standard does not exist, the basis for calibration shall be fully documented and approved by the appropriate personnel. It is the responsibility of the user to select, verify, and use the correct standard in accordance with an approved procedure or established practice.

Physical and chemical standards shall have certifications traceable to NIST. EPA, or other recognized agencies. Supporting documentation on all reference standards and equipment shall be maintained by the user and be readily available for reference and inspection. Standards that are repackaged or split shall also have traceable lot or batch numbers transferred onto the new container.

\subsubsection{Calibration Failure}

Each individual user of M\&TE is responsible for checking the calibration status of equipment to be used and confirming the acceptable calibration status prior to use. Equipment for which the periodic calibration period has expired, equipment that fails calibration, or equipment that becomes inoperable shall be tagged "out-of-service" and, when possible, segregated to prevent inadvertent use. M\&TE shall be repaired and/or recalibrated by the appropriate vendor, 
manufacturer, or qualified personnel prior to being returned to service. Results of activities performed using equipment that is found to be out of calibration shall be evaluated for adverse affects. If the activity results are adversely affected, the evaluation shall be documented as a nonconformance and the appropriate personnel shall be notified.

\subsubsection{Preventive Maintenance}

Periodic preventive maintenance shall be required for all field and laboratory equipment. Preventive maintenance schedules, practices, and a list of spare parts shall be developed by all RCRA Industrial Sites Subproject participants and documented throughout the life of the subproject. Major instruments and equipment shall be covered by annual service contracts with manufacturers or other qualified organizations.

Information pertaining to the histories of equipment maintenance shall be kept in individual logs or files for each instrument. Instrument manuals shall be kept on file as references for equipment needs and repair. The frequency of preventive maintenance shall be based on manufacturers' recommendations and the users' professional knowledge and experience.

\subsection{Data Reduction, Validation, and Reporting}

Data reduction refers to computations and calculations performed on raw data. Data validation is a systematic process for reviewing data against a set of criteria to ensure that the data are adequate for the intended use. Data reporting is the documentation of data reduction and validation results.

\subsubsection{Data Reduction}

Data reduction includes, but is not limited to, summary tables, statistics (e.g., means, standard deviations, variances, standard errors, and confidence limits), assessments relative to the parameters with respect to levels of concern, and numerical models. Statistically acceptable data-analysis procedures shall be implemented for all data-reduction steps. Detailed procedures for data reduction can be found in the User's Guide to the Contract Laboratory Program (EPA, 1991). Numerical reduction of field and analytical data shall be formally checked using the standard process outlined in this section. Checking must be performed prior to the presentation of results. If unchecked results are to be presented, transmittals or 
subsequent calculations based on these results must be marked "preliminary" until the results are checked and determined to be correct.

\subsubsection{Data Validation}

Following a systematic effort to review data, data validation shall be implemented to ensure data quality is acceptable (DOE, 1991). Data validation consists of data editing, screening, checking, auditing, verification, and review (EPA, 1983). Data validation, including the checking of calculations, shall be performed by an individual(s) other than the one who performed the original work or specified the method.

The laboratory data to verify closure will be validated in a manner consistent with EPA functional guidelines for both organic and inorganic compound analyses (EPA, 1988a and 1988b). This validation process shall include a review of laboratory reports to ensure that proper analytical methods were used, detection limits were appropriate, data are accurate and precise and the proper number of significant figures were reported, and results were calculated properly. Data validation shall also include the review of analytical instrument calibration and tuning to verify that proper standards were prepared and used during calibration. All laboratory data shall be reviewed for completeness.

\subsubsection{Laboratory Data Reporting}

Analytical data reports must contain, at a minimum, the following information:

- A cover page with the reviewer's signature, data qualifiers, and a description of any technical difficulties encountered during the analyses

- The date the sample was received

- The date the sample was prepared

- The date the sample was analyzed

- The sample identification number

- The laboratory sample identification number

- The analytical method reference number 
- Analytical results

- Tabulated QC sample results

- Instrument tuning and calibration results

- The final copy of the COC/AR form, with appropriate signatures.

Validated data shall be reviewed to determine whether they meet the DQOs of the investigation. The data shall be reviewed to ensure that the required number of samples were collected, critical samples were collected and analyzed, and the results passed data-validation criteria. The data shall also be reviewed to determine whether detection limits were met. Data-reporting techniques shall be in accordance with the project data-reporting requirements; data-reporting procedures shall be consistent with those found in the User's Guide to the Contract Laboratory Program (EPA, 1991). 


\subsection{Criteria 6 - Design}

Any items or processes designed in support of the RCRA Industrial Sites Subproject shall be in accordance with a documented design control process and based on sound engineering and scientific principles and using the appropriate standards. The acceptability and adequacy of the design product shall be verified or validated by qualified individual(s) other than those who performed the original design. Verification and validation shall be completed prior to approval and implementation of the design. Design records shall include the design steps and sources of input that support the final output. The final design output shall be approved in accordance with the participants' internal procedures. Changes or modifications to the final design shall be subject to the same control measures and approvals as applied to the original design. 


\subsection{Criteria 7 - Procurement}

Items and services of a technical nature provided to the RCRA Industrial Sites Subproject shall be of a quality that meets the requirements of the project. Subproject participants shall establish controls to ensure that procured equipment and services meet or exceed specifications and that systems are in place to track items and confirm the delivery of procured items and services. Subproject participants shall have a program in place, invoking the appropriate quality-related requirements of the contractor's QA program plans and procedures and this QAPjP, for the procurement of items and services. All procurement documents shall be submitted to QA for review to ensure that the applicable quality-affecting requirements have been included. QA shall initial and date the procurement documents to verify that the review has taken place.

Procurement documents shall define the scope of work for the item or service being procured, specifications, and any documentation required. Technical requirements shall either be directly included in the procurement documents or included by reference to specific drawings, specifications, procedures, regulations, or codes that describe the items or services to be furnished. Documentation required to provide evidence that items and services conform to quality standards shall be identified in the procurement documents. The procurement documents shall require that all purchased and rented M\&TE be calibrated to national standards prior to acceptance and a calibration sticker affixed to the instrument. Calibration certification and instrument manufacturers ' manuals shall be available in project files for all M\&TE.

If applicable, procurement documents shall provide free access to the subcontractors' facilities, including their subtier facilities, work areas, and records for surveillance, inspection, and audit to verify acceptability. Objective evidence of conformance to procurement requirements shall be thoroughly evaluated. The authority to stop work, based on significant quality problems, shall be clearly stated. 


\subsection{Criteria 8 - Inspection and Acceptance Testing}

Inspections and acceptance testing shall be accomplished in accordance with approved inspection documents and test procedures that reflect acceptance and performance criteria. Individuals performing inspections and acceptance testing shall be independent of those who performed the work. M\&TE used in the performance of inspections or acceptance tests shall be calibrated and properly maintained. Any item or work determined to be defective shall be controlled in accordance with Section 3.3 of this QAPjP. 
Resource Conservation and Recovery Act Industrial Sites Quality Assurance Project Plan

Part D

Assessment

Nevada Environmental Restoration Project 


\subsection{Criteria 9 - Management Assessment}

Planned and periodic assessments shall be conducted and shall involve management at all levels. Management assessments shall include the direct participation of senior management. The primary emphasis of management assessments is to evaluate the implementation of the integrated QA program and identify problems that hinder the achievement of objectives. Contractor management shall conduct an assessment at the conclusion of each RCRA Industrial Site closure and document this assessment in a Lessons Learned Report. The management assessment shall focus on such issues as the:

- Adequacy of implementation of the integrated QA program, with particular emphasis on quality improvement

- Existence of any management biases or organizational barriers that impede the improvement process

- Adequacy of the appraised organization's structure, staffing, and physical facilities

- Existence of effective training programs.

The results of the assessment shall be documented in a final report and issued to the appropriate managers. Senior management has the primary responsibility to ensure the timely follow-up of corrective actions, including an evaluation of the effectiveness of management's actions. Results of the management assessment shall be entered into a tracking system for the purposes of identifying trends and lessons learned. 


\subsection{Criteria 10 - Independent Assessments}

This section establishes the methods and responsibilities for planning, scheduling, and performing independent assessments in the form of audits and surveillances of quality affecting RCRA Industrial Sites Subproject activities. Audits and surveillances shall be performed to verify compliance with the QA program and to determine the effectiveness of its implementation. The focus of these assessments shall be on improving items and processes. Subproject participants shall have QA programs and procedures in place that satisfy the requirements of DOE/NV Order $5700.6 \mathrm{C}$ for the conduct of independent assessments.

\subsection{Audits}

An audit is a planned and documented activity that evaluates specified components of a task against approved requirements, plans, and procedures. Audits shall examine the availability, adequacy, and implementation of work instructions and assess the effectiveness of management and work process controls.

\subsubsection{Audit Schedule}

Audits shall be scheduled as early as feasible in the life of an activity. Thereafter. audits shall be scheduled at a frequency commensurate with the extent of activity of an element(s), previously identified deficiencies of the element(s), and the importance of the element(s). Unscheduled audits may be performed to supplement scheduled audits based on. but not limited to, results of previous audits, surveillances and management assessments. nonconformance reports, corrective actions, and identified trends.

\subsubsection{Audit Teams}

Commensurate with the scope, complexity, or unique nature of the activities to be audited, personnel shall be selected for auditing assignments based on their abilities, specialized technical training, experience, and education. Lead Auditors shall be qualified in accordance with ANSI N45.2.23 or ASME NQA-1, or certified by other recognized certification programs. Technical Specialists are individuals with a specialized knowledge of the area being audited. These Technical Specialists may be selected to participate under the guidance 
of a Lead Auditor. All selected auditors shall be independent of any direct responsibility for performing the activities to be audited. Auditors and Technical Specialists shall have, or be given, appropriate training in audit techniques and shall be indoctrinated in the specifics of the audit.

\subsection{Surveillances}

Audits shall be supplemented with surveillances to verify the effectiveness of the QA program. Surveillances are narrow in scope and directed at specific project activities. A surveillance is the act of monitoring or observing an item or activity to verify conformance to specified requirements.

Surveillances do not require the same level of planning and scheduling as audits and shall be performed based on the potential for adverse affect. The extent and frequency of surveillances shall reflect the importance of the work activity, results of previous surveillances and/or audits, trend reports, and the inherent risks involved. Surveillance personnel shall be knowledgeable in, and not directly responsible for, the activities under surveillance. 


\subsection{References}

American National Standards Institute, N45.2.23. 1989.

American Society of Mechanical Engineers, NQA-1-1989.

CFR, see Code of Federal Regulations.

Code of Federal Regulations, "Environmental Protection Agency," Title 40, Part 792, Washington, DC.

Code of Federal Regulations, "Hazardous Materials Shipping Regulations," Title 49, Parts 170 through 173, Washington. DC.

DOE, see U.S. Department of Energy.

EPA, see U.S. Environmental Protection Agency.

Resource Conservation and Recovery Act of 1976, Public Law No. 94-580, Washington, DC.

U.S. Department of Energy, 1991, DOE Order 5700.6C, "Quality Assurance," Office of Nuclear Energy/Office of Environmental Safety and Health, Washington, DC.

U.S. Department of Energy, 1988, DOE Order 1324.2A, "Records Disposition," Office of Nuclear Energy/Office of Environmental Safety and Health, Washington. DC.

U.S. Environmental Protection Agency 1991, User's Guide to the Contract Laboratory Program. CLP SOW, Washington. DC.

U.S. Environmental Protection Agency, 1990, Contract Laboratory Program. Statement of Work for Inorganic Analysis, Multi-Media, Multi-Concentration, CLP SOW 788, Washington, DC.

U.S. Environmental Protection Agency, 1988a, Contract Laboratory Program. Statement of Work for Organic Analysis, Multi-Media, Multi-Concentration, CLP SOW 2/88, Washington, DC.

U.S. Environmental Protection Agency, 1988b, Contract Laboratory Program, Laboratory Data Validation Functional Guidelines for Evaluating Organic Analyses, CLP SOW, Washington, DC. 
U.S. Environmental Protection Agency, 1988c, Contract Laboratory Program. Laboratory Data Validation Functional Guidelines for Evaluating Inorganic Analyses, CLP SOP, Washington, DC.

U.S. Environmental Protection Agency, 1987, Data Quality Objectives for Remedial Response Activities, EPA/540/G-87/003, Washington, DC.

U.S. Environmental Protection Agency, 1986, Test Methods for Evaluating Solid Waste, Physical Chemical Methods, SW-846, 3rd editions, Office of Solid Waste and Emergency Response, Washington, DC.

U.S. Environmental Protection Agency, 1983, Interim Guidelines and Specifications for Preparing Quality Assurance Project Plans, QAMS-005/80, EPA-600/4-83-004, Washington, DC.

U.S. Department of Transportation, Hazardous Materials Shipping Regulations. Title 49 Code of Federal Regulations, Parts 170-173. 